\title{
Nomenclature and syntaxonomic notes on some high-rank syntaxa of the European grassland vegetation
}

\author{
Romeo Di Pietro ${ }^{1}$, Jean-Paul Theurillat ${ }^{2}$, Jorge Capelo ${ }^{3}$, Federico Fernández- \\ González $^{4}$, Massimo Terzi ${ }^{5}$, Andraž Čarni ${ }^{6}$ \& Ladislav Mucina ${ }^{7}$
}

\begin{abstract}
Di Pietro, R., Theurillat, J.P., Capelo, J., Fernández-González, F., Terzi, M., Čarni, A. \& Mucina, L. Nomenclature and syntaxonomic notes on some high-rank syntaxa of the European grassland vegetation. Lazaroa 36:79-106 (2015).

We present descriptions of a new order (Ranunculo cortusifolii-Geranietalia reuteri) and of a new alliance (Stachyo lusitanicae-Cheirolophion sempervirentis) for the herbaceous fringe communities of Macaronesia and of the southwestern Iberian Peninsula, respectively. A new alliance, the Polygalo mediterraneae-Bromion erecti (mesophilous post-cultural grasslands), was introduced for the Peninsular Italy. We further validate and typify the Armerietalia rumelicae (perennial grasslands supported by nutrient-poor soils on siliceous bedrocks at elevations characterized by the submediterranean climate of south-central Balkan Peninsula), the Securigero-Dasypyrion villosae (lawn and fallow-land tall-grass annual vegetation of Italy), and the Cirsio vallis-demoni-Nardion (acidophilous grasslands on siliceous substrates of the Southern Italy). Nomenclatural issues (validity, legitimacy, synonymy, formal corrections) have been discussed and clarified for the following names: Brachypodio-Brometalia, Bromo pannonici-Festucion csikhegyensis, Corynephoro-Plantaginion radicatae, Heleochloion, Hieracio-Plantaginion radicatae, Nardetea strictae, Nardetalia strictae, Nardo-Callunetea, Nardo-Galion saxatilis, Oligo-Bromion, Paspalo-Heleochloetalia, Plantagini-Corynephorion and Scorzoneret alia villosae.
\end{abstract}

Keywords: Chenopodietea, International Code of Phytosociological Nomenclature, EuroVegChecklist, Festucetea indigestae, Festuco-Brometea, Nardetea strictae, Phytosociology, Stipo giganteae-Agrostietea castellanae, Trifolio-Geranietea.

Resumen: Di Pietro, R., Theurillat, J.P., Capelo, J., Fernández-González, F., Terzi, M., Čarni, A. \& Mucina, L. Notas nomenclaturales y sintaxonómicas sobre diversos sintáxones de alto rango de los pastizales europeos. Lazaroa 36: 79-106 (2015).

Se describen un nuevo orden (Ranunculo cortusifolii-Geranietalia reuteri) y una nueva alianza (Stachyo lusitanicaeCheirolophion sempervirentis) para la vegetación herbácea de linderos forestales de los archipiélagos de Canarias y Madeira y del suroeste de la Península Ibérica, respectivamente, así como una nueva alianza (Polygalo mediterraneae-Bromion erecti) para los pastizales mesófilos de campos abandonados de Italia peninsular. Además, se valida y tipifica el orden Armerietalia rumelicae (pastos vivaces de suelos pobres en nutrientes sobre sustratos silíceos, propios de los climas submediterráneos del centro y sur de la Península Balcánica), y las alianzas Securigero-Dasypyrion villosae (vegetación de praderas y eriales dominados por gramíneas altas en Italia) y Cirsio vallis-demoni-Nardion (cervunales acidófilos de Italia meridional). Se discuten y clarifican distintos aspectos nomenclaturales (validez, legitimidad, sinonimia, correcciones formales) de los siguientes nombres: Brachypodio-Brometalia, Bromo pannonici-Festucion csikhegyensis, Corynephoro-Plantaginion radicatae, Heleochloion, Hieracio-Plantaginion radicatae, Nardetea strictae, Nardetalia strictae, Nardo-Callunetea, Nardo-Galion saxatilis, Galio saxatilis-Nardion, Oligo-Bromion, Paspalo-Heleochloetalia, Plantagini-Corynephorion y Scorzoneretalia villosae.

Palabras clave: Chenopodietea, ICPN, EuroVegChecklist, Festucetea indigestae, Festuco-Brometea, Nardetea strictae, Fitosociología, Stipo giganteae-Agrostietea castellanae, Trifolio-Geranietea.

\footnotetext{
${ }^{1}$ Department of Planning, Design and Technology of Architecture, Section Environment and Landscape, University of Rome "La Sapienza", Via Flaminia 72, I-00196 Rome, Italy.

${ }^{2}$ Centre Alpien de Phytogéographie, Fondation J.-M. Aubert, Case postale 71, CH-1938 Champex-Lac, Switzerland. Section of Biology, University of Geneva, Case postale 60, CH-1292 Chambésy, Switzerland.

${ }^{3}$ Instituto Nacional de Investigação Agrária e Veterinária, Av. Da República, Quinta do Marquês, 2780-159 Oeiras, Portugal

${ }^{4}$ Institute of Environmental Sciences (ICAM), University of Castilla-La Mancha, E-45071 Toledo, Spain.

${ }^{5}$ Institute of Bioscience and Bioresources (IBBR), National Research Council of Italy (CNR), Via Amendola 165/a, I-70126 Bari, Italy.

${ }^{6}$ Institute of Biology, Scientific Research Center of the Slovenian Academy of Sciences and Arts, Novi trg 2, SI-1001 Ljubljana, Slovenia. University of Nova Gorica, Vipavska 13, SI-5000 Nova Gorica, Slovenia, Macedonian Academy of Sciences and Arts, Bul. Krste Misirkov 2, MK-1000 Skopje, Republic of Macedonia.

${ }^{7}$ Iluka Chair in Vegetation Science and Biogeography, School of Plant Biology, The University of Western Australia, 35 Stirling Highway, Crawley WA 6009, Perth, Australia. Department of Geography and Environmental Studies, Stellenbosch University, Private Bag X1, Matieland 7602, Stellenbosch, South Africa. Department of Botany and Microbiology, College of Science, King Saud University, P.O. Box 2455, Riyadh 11451, Saudi Arabia. E-mail: Laco.Mucina@uwa.edu.au (corresponding author).
} 


\section{INTRODUCTION}

During the preparation of the publication 'Vegetation of Europe: Hierarchical floristic classification system of vascular plant, bryophyte, lichen, and algae communities' (MucINA \& al., submitted; hereafter referred to as 'EuroVegChecklist'), thousands of published syntaxonomical concepts of European phytosociological classes, orders and alliances have been assessed. The syntaxon names related to these concepts were checked for the compliance with the rules of the International Code of Phytosociological Nomenclature (WeBER \& al., 2000). In many cases, these revisions revealed a need for formal description of new vegetation units, nomenclature changes or adjustments, or stabilization of the current names by their typification. The present paper is one of the series of papers (e.g. DidUKH \& MUCINA, 2014; ČARNI \& MUCINA, 2015; CHYTRÝ \& al., 2015; DANIËLS \& al., 2015; LYSENKO \& MuCINA, 2015) addressing these issues.

The aim of this paper is to formally describe several new syntaxa, perform nomenclatural changes, and discuss nomenclatural issues in some grassland or herb-rich vegetation types of Europe and Macaronesia.

The nomenclature of the plant species used in this paper follows Euro+Med Plant Base (2006-, see www.emplantbase.org.), except for Linum, Polygala, Rumex and Viola (here the original names as they appeared in the discussed publications, were used).

POLYGALO MEDITERRANEAE-BROMION ERECTI, A NEW ALLIANCE FROM THE APENNINES (PENINSULAR ITALY)

(by Romeo Di Pietro)

Polygalo mediterraneae-Bromion erecti (Biondi, Allegrezza et Zuccarello 2005) Di Pietro stat. nov. hoc loco

(Brometalia erecti, Festuco-Brometea)

Basionym (suballiance): Polygalo mediterraneae-Bromenion erecti Biondi, Allegrezza et Zuccarello 2005 (BIONDI \& al., 2005: 157, 159).
Name-giving taXa: Bromopsis erecta, Polygala nicaeensis subsp. mediterranea.

TYPE (holotypus): Centaureo bracteataeBrometum erecti Biondi, Ballelli, Allegrezza, Guitian et Taffetani 1986 (BIONDI \& al., 1986: Doc. Phytosociol. 10: 117-126).

DiAgnostic TAXA: Brachypodium rupestre, Carex flacca subsp. serrulata, Centaurea jacea subsp. gaudinii, Cota tinctoria subsp. australis, Dorycnium pentaphyllum subsp. herbaceum, Galium verum, Linum viscosum, Ononis masquillieri, O. spinosa, Ornithogalum pyramidale, Polygala flavescens, P. nicaeensis subsp. mediterranea, Stachys cretica subsp. salviifolia, Trifolium incarnatum subsp. molinerii, $T$. ochroleucon.

DiAGNOSIS: mesophilous grasslands supported by marl-arenaceous and clayey substrates in the colline, submontane and lower montane altitudinal belts of the Apennines.

DisTRIBUTION: Apennines (Italy).

SYNTAXONOMY: The meso-xerophilous grasslands dominated by Brachypodium rupestre were generally considered as a transitory vegetation state forming after abandonement of intensively grazed and mown pastures and meadows (BONANOMI \& Allegrezza, 2004; BonANOMI \& al., 2006). Brachypodium rupestre is competitive also in forest clearings (LUCCHESE, 1990), and appears to be abundant in the undergrowth of thermophilous oak and mixed open forests and associated shrublands, especially on the Tyrrhenian macroslope of the Apennines (Blasi \& Di Pietro, 1998; Blasi \& al., 2000, 2001; Di PIETRO \& al., 2010). In natural habitats, $B$. rupestre plays a subordinate role in the Bromopsis erecta dry grasslands as well as in the Lolium-Cynosurus mesophilous grasslands. It attains dominance in semi-mesophilous grasslands developed on clayey or marly-arenaceous substrates in the colline and lower-montane altitudinal belts. As a dominating element, it also occurs on abandoned formerly cultivated terraces on slopes of coastal ranges where leached, clayrich terra rossa soils occur. The $B$. rupestre grasslands of the Peninsular Italy are currently classified in the Dorycnio-Brachypodietum, supported by the marly-arenaceous substrates of the Northern Apennines (UBALDI, 1988), the Polygalo 
flavescentis-Brachypodietum rupestris in the submontane belt (LuCCHESE \& al., 1995), and the Galio lucidi-Brachypodietum rupestris in the subcoastal zones of the Tyrrhenian macroslope of the Central Apennines (Di Pietro \& Blasi, 2002). In the Southern Italy, the Polygalo mediterraneaeBrachypodietum rupestris was described from the submontane and lower montane belts of the Lucanian Apennines (Di Pietro \& al., 2014). Some $B$. rupestre communities (not classified as associations) were also described for the Northern Apennines (BARCELLA \& al., 2014).

BIONDI \& al. (1995) classified the Brachypodium rupestre communities in the Italian endemic alliance Phleo ambigui-Bromion erecti (Brometalia erecti, Artemisio albae-Bromenalia erecti). The mixed Brachypodium rupestre and Bromopsis erecta communities (e.g. Centaureo bracteatae-Brometum erecti, PseudolysimachioBrometum erecti, Ononido masquillieri-Brometum erecti) were classified by the latter authors in the Bromion erecti or in the mesophilous suborder Leucanthemo-Bromenalia erecti. Subsequently BIONDI \& al. (2005) classified all the non-calciphilous grasslands of the mesotemperate bioclimatic belt of the northern-central regions of the Apennines in a new suballiance - the Polygalo mediterraneae-Bromenion erecti (type association: Centaureo bracteatae-Brometum erecti). Although the latter authors have not classified the Polygalo flavescentis-Brachypodietum rupestris (the only Brachypodium rupestre dominated community considered in their paper) in the PolygaloBromenion, they had included Brachypodium rupestre in the list the character-species of their new suballiance. On the other hand, they included here some pioneer communities (such as the Coronillo minimae-Astragaletum monspessulani and the Astragalo monspessulani-Scabiosetum crenatae) supported by the marl-clay, highly eroded substrates.

The scheme proposed by BIONDI \& al. (1995, 2005) was modified by UBALDI $(1997,2003$, 2011), who proposed three new alliances, namely the Botriochloo-Bromion Ubaldi 1997, the Coronillo-Astragalion Ubaldi 2003 and the Filipendulo-Bromion Ubaldi 2011 (in addition to the Bromion erecti) to classify the Apennine dry and semi-mesophilous grasslands of the marly-arenaceous and marly-calcareous substrates. Ubaldi (1.c.) kept the DorycnioBrachypodietum (the only Brachypodium rupestre community cited in the Ubaldi's works) in the Bromion erecti together with some other semi-mesophilous mixed $B$. rupestre and Bromopsis erectus communities such as the Centaureo bracteatae-Brometum and the Pseudolysimachio-Brometum.

FogGi \& al. (2014) described other semimesophilous non-calciphilous grasslands for the Tuscan Apennines, and classified those in a new suballiance (Festuco inopsis-Bromenion erecti). According to these authors, this suballiance should include the pioneer, acidophilous, oligotrophic communities of the Bromion erecti on marly-clayey and arenaceous substrata; it was distinguished from the Polygalo-Bromenion Biondi et al. 2005 as being characterized by a strong mesophilous component and typical of post-cultural environments.

In my opinion the pioneer communities developed on flyschoid eroded substrates as well as the xerophilous communities dominated by Bromopsis erectus occurring both on limestone or marly-calcareous substrates should be considered as syntaxonomically distinct from the mesophilous (natural or post-cultural) Brachypodium rupestre grasslands. For this reason I propose to classify the pioneer grasslands of sandy-clayey substrates characterised by a high subshrub and shrub component (Astragalus monspessulanum, Coronilla minima, Lomelosia crenata etc.) in the Coronillo-Astragalion Ubaldi 2003. I suggest also classifying the Bromopsis erecta open dry grasslands of the Central and Southern Apennines on limestone in the Cytiso-Bromion, and the dry grasslands on calcareous marly-arenaceous substrates of the Central and Northern Apennines in the Botriochloo-Bromion Ubaldi 1997 or in the Festuco-Bromion Barbero et Loisel 1972.

As for the natural grasslands developed of the post-cultivation, abandoned or very extensively used habitats on marly-clayey or pelithic-arenaceous substrates as well as those developed on colluvial leached soils over limestone, I propose 
here a new alliance: the Polygalo mediterraneaeBromion erecti. The Polygalo-Bromion differs from similar syntaxa occurring in Central Europe by the presence of Mediterranean floroelements, such as orchids (e.g. Anacamptis papilionacea, Ophrys bertolonii, O. fusca, O. garganica, $O$. incubacea, Orchis antropophora, Serapias vomeracea) as well as Centaurea jacea subsp. gaudinii, Carex flacca subsp. serrulata, Polygala nicaeensis subsp. mediterranea and Stachys cretica subsp. salviifolia missing in the Central European grasslands. Brachypodium rupestre itself is almost completely absent from Central Europe where it is substituted by Brachypodium pinnatum. According to a recent taxonomical revision (BARTOLUCCI \& DOMINA, 2014), Thymus longicaulis (very common especially in the $B$. rupestre communities of the Apennines) is endemic to the Peninsular Italy and the Western Balkans and it is substituted by other taxa of the Thymus serpyllum group in Central Europe.

On the basis of the most important syntheses published on dry and semi-mesophilous grasslands published since 1990 (RoYer, 1991; RoDwELL, 1992; MuCina \& KolBeK, 1993; Rivas-MartínEZ \& al., 2001; Rodwell \& al., 2002; Dengler, 2004; BiONDI \& al., 2005; DENGLER \& al., 2006), the European vegetation system now reflects the importance of biogeography and can be summarised (at the level of alliance) as follows:

Chrysopogono-Danthonion (the Balkans)
Cirsio-Brachypodion (eastern regions of
Central Europe)
Filipendulo-Helictotrichion (North Europe)
Gentiano-Helictotrichion pratensis (Northern
France and the British Isles)
Polygalo mediterraneae-Bromion erecti
(Apennine Peninsula).
Potentillo splendentis-Brachypodion (Iberian
Peninsula)

VALIDATION AND SYNTAXONOMICAL DISCUSSION ON THE SECURIGERODASYPYRION, AN ALLIANCE OF THE MEDITERRANEAN ABANDONED PASTURES (by Romeo Di Pietro)

\section{Securigero securidacae-Dasypyrion villosi Cano-Ortiz, Biondi et Cano in Cano-Ortiz \& al. ex Di Pietro all. nov. hoc loco}

(Brometalia rubenti-tectorum, Chenopodietea)

Synonyms: Securigero securidacae-Dasypyrion villosi Cano-Ortiz, Biondi et Cano in Cano-Ortiz et al. 2014 nom. inval. (ICPN art. 5); Securigero securidacae-Dasypyrion villosi Cano-Ortiz, Biondi et Cano ex Cano-Ortiz, Biondi et Cano in Biondi, Allegrezza, Casavecchia, Galdenzi, Gasparri, Pesaresi, Poldini, Sburlino, Vagge et Venanzoni 2015 nom. inval. (ICPN art. 2b).

NAMe-giving SPecies: Dasypyrum villosum, Securigera securidaca.

TYPe (holotypus hoc loco): Vulpio ligusticaeDasypyretum villosi Fanelli 1998 (FANELLI, 1998: Rend. Fis. Acc. Lincei 9: 149-170).

Diagnostic taXA: Anisantha diandra, A. rigida, Avena sterilis, Clinopodium nepeta, Crepis neglecta, Dasypyrum villosum, Foeniculum vulgare, Hordeum bulbosum, Knautia integrifolia, Lagurus ovatus, Tyrimnus leucographus, Vicia villosa, Vulpia ligustica.

Distribution: Apennines (Italy) and probably SW Balkans (sub-coastal zones of the Southern Albania and the Northern Greece.

Diagnosis: Central Mediterranean and submediterranean mesophilous lawn and fallow vegetation dominated by tall annual or shortlived perennials.

SYNTAXONOMY: The Dasypyrum villosum communities are one of the most common anthropogenic grassland types of the Peninsular Italy. They occur both in urban environments (road verges, traffic flowerbed dividers, etc.) and in rural areas (abandoned fields, edges etc.). Pignatti (1952) described the 'Ass. a Bromus villosus ed Haynaldia villosa Pign. 1953' from the sub-coastal habitats of the Venice Lagoon and classified it in the Sisymbrion officinalis (Chenopodietalia albi, Stellarietea mediae in his classification scheme) as a vegetation unit substituting the Hordeetum murini on the sandy coastal fallow lands. This community was also recognized also by BIONDI \& al. $(1999,2001)$ and FiLIGHEDDU \& al. (1999) in other regions of Italy (Marche and Sardinia) as the Bromo-Dasypyretum 
villosi and classified in the Hordeion leporini. Gentile (1962) and Ferro (1980) described a thermophilous form of the Dasypyrum villosum grasslands in Sicily, emphasizing the regional role of the thermomediterranean component. FANELLI (1998) described two associations from the Rome countryside, the Laguro-Dasypyretum (coastal regions) and the Vulpio-Dasypyretum (inland regions); both were classified in the EchioGalactition (Thero-Brometalia, TheroBrachypodietea, in his syntaxonomic scheme). AllegrezZA (2003) identified a peculiar anthropogenic Dasypyrum villosum grassland type in the Central Apennines (Marche, Umbria) characterized by notable occurrence of the MolinioArrhenatheretea, Festuco-Brometea and Artemisietea vulgaris elements, and classified this vegetation type preliminary in the 'Stellarietea mediae' and the Hordeion leporini. In GUGLIELMO $\&$ al. (2012) the D. villosum communities occurring in abandoned groves surrounding an archeological site in southeastern Sicily, were provisionally included in the Echio-Galactition. BLASI \& al. (2012) proposed the Erisymo-Dasypyretum to typify a sub-nitrophilous grassland community occurring in the colline belt of the Northern Latium, and classified this community in the Taeniathero-Aegilopion (Thero-Brometalia, Stellarietea mediae, in his classification). Finally, CANO-ORTIZ \& al. (2014) described a new association - the Securigero-Dasypyretum villosi from the Gargano region (Apulia), and classified this unit in the Securigero-Dasypyrion villosi. An attempt to validate the invalidly published Securigero-Dasypyrion villosi by BIONDI \& al. (2015) was not successful due to the lack of a bibliographic reference to the type association of the alliance (ICPN art. 2).

The Dasypyrum villosum grasslands also occur in the Balkans (Trifolio molinieri-Haynaldietum villosae Buia et al. 1959: RAŢIU, 1968; BoşCAIU \& ReSMERIŢĂ, 1969; PĂUn \& al., 1970; ROMAN, 1974; GRIGORE \& COSTE, 1979), however due to the important role of the Festuco-Brometea species such as Botriochloa ischaemum, Chrysopogon gryllus, Festuca valesiaca) and some MolinioArrhenatheretea species, this vegetation differs from the Dasypyrum grasslands described from
Italy. PIRINI \& al. (2014) described from the Central Greece similar Artemisia campestrisDasypyrum villosum grassland (supported by dry and base-rich substrates). Most recently FANELLI \& al. (2015) classified two relevés sampled in the Buna River valley (Northern Albania) in the Bromo-Dasypyretum villosi. This association was included in the Laguro ovati-Bromion rigidi Géhu et Géhu-Franck 1985.

The classification of the Dasypyrum villosum communities in the high-rank syntaxa is contentious and the long list of classes (see Table 1), spanning the Stellarietea mediae, MolinioArrhenatheretea, Thero-Brachypodietea, FestucoBrometea, and Tuberarietea guttatae, is indicative of the problem.

Although FANELLI (1998) provisionally classified the Dasypyrum villosum associations of the Rome countryside in the Echio-Galactition, he highlighted the possibility of including the Dasypyrum villosum communities in the VulpioLotion, an alliance originally described from the Dalmatian coast (HoRvaTIĆ, 1963) to capture the slightly acidophilous therophyte-rich grassland vegetation. Fanelli (1.c.), however, also reported on the lack of an alliance including all the Central and Eastern Mediterranean grassland vegetation "dominated by tall annual or shortly perennial Gramineae".

The therophyte dominant component occurring in the Dasypyrum villosum community lead other authors (IzCO, 1977; PIRONE \& al., 1997; Gigante \& Venanzoni, 2007; Blasi \& al., 2012) to classify these communities in the Taeniathero-Aegilopion geniculatae. The latter alliance, however, is dominated by low-grown annual therophytes, whereas tall annual grasses (e.g. Avena barbata, A. sterilis, Dasypyrum villosum, Vulpia ligustica), mixed with tall perennial grasses (Dactylis glomerata, Holcus lanatus, Hordeum bulbosum, Lolium perenne, L. multiflorum, Poa trivialis), dominate the Italian Dasypyrum villosum communities. The Taeniathero-Aegilopion occurs prevalently in the inland regions of the Spanish Meseta having sub-continental climatic conditions (IzCO, 1977; Rivas-Martínez \& IzCO, 1978) where the most representative species of the Italian Dasypyrum 
villosum communities, namely Dasypyrum villosum and Vulpia ligustica, are absent.

I exclude a possible reference of these grasslands to the Hordeion leporini - an alliance including the Mediterranean ruderal communities rich in winter annual grasses. The Hordeion leporini is to be considered a geographical analogon of the temperate Sisymbrion officinalis (see Mucina, 1991). The Hordeion leporini exhibits an anthropogenic character and it is usually restricted to habitats subject to permanent disturbance or increased nutrient supply (e.g. country roadsides, archeological areas, garbage dumps, small-farm walls, and the like). It is never subjected to haymaking, which is, on the contrary, a common practice in the Dasypyrum villosum communities. Tall herbs rarely dominate in the Hordeion leporini. Finally, the classification of the Dasypyrum villosum grasslands into the Laguro-Bromion rigidi is not considered here as a viable solution as well since the latter alliance is comprising ephemeral therophytic vegetation on disturbed coastal sand dunes of the Atlantic coast of France.

The classification of the Dasypyrum villosum grasslands into the Vulpio-Lotion, the Taeniathero-Aegilopion or the Hordeion lepori$n i$ is not considered here as convincing. Here I prefer to adopt the concept of an alliance as suggested by FANELLI (1988) and CANO-ORTIZ \& al. (2014). Accordingly, the alliance Securigero securidacae-Dasypyrion villosi Cano-Ortiz, Biondi et Cano in Cano-Ortiz et al. 2014 nom. inval. (ICPN art. 5) is here validated.

The core distribution area of the Securigero securidacae-Dasypyrion villosi is the Apennine Peninsula, however it is possible that this are might be extended in the southwestern Balkans (Greece and Albania), as suggested by FANELLI (2011) and FANELLI \& al. (2015) and confirmed by personal observations for the footslopes of Mount Nemerçkë (Albania).

The high-rank syntaxa, to which the SecurigeroDasypyrion should be classified remain a critical issue. It is apparent that the occurrence of perennial mesophilous species (Cynosurus cristatus, Holcus lanatus, Lolium perenne, Phleum pratense, Plantago lanceolata etc.) in the Dasypyrum villosum grasslands developed on deep and moist soils could suggest classification in the Molinio-Arrhenatheretea. Nevertheless I prefer to include the Securigero-Dasypyrion in the Brometalia rubenti-tectorum (Chenopodietea) due to the occcurrence of significant anthropogenic component always associated with the Dasypyrum villosum grasslands; also the high number of the Helianthemetea mediterranean therophytes plays a supportive role.

The following associations can currently be included in the Securigero-Dasypyrion villosi:

Bromo diandri-Dasypyretum villosi Pignatti 1952

Eryngio amethystini-Dasypyretum villosi Rosati et al. 2012

Laguro ovati-Dasypyretum villosi Fanelli 1998 Securigero securidacae-Dasypyretum villosi Cano-Ortiz et al. 2014

Vulpio ligusticae-Dasypyretum villosi Fanelli 1998

The Hordeum bulbosum and Vulpia ligustica submontane communities described for the Tyrrheniam macroslope of the Central Apennines (BLASI \& al., 2009), originally classified in the Cynosurion cristati, could also be considered as belonging to a mesophilous section of the Securigero-Dasypyrion.

\section{A NEW ALLIANCE OF FRINGE VEGETA- TION FROM SOUTHERN IBERIA (by Jorge Capelo)}

\section{Stachyo lusitanicae-Cheirolophion semperviren- tis (Capelo 1996) Capelo stat. nov. hoc loco (Asphodeletalia macrocarpi, Trifolio-Geranietea)}

BASIONYM: Stachyo lusitanicae-Cheirolophenion sempervirentis Capelo 1996 (CAPELO, 1996: 124-125).

NAME-GIVING TAXA: Cheirolophus sempervirens, Stachys germanica subsp. cordigera (syn. S. lusitanica).

HoLOTYPUS: Leucanthemo sylvatici-Cheirolophetum sempervirentis Costa et al. 1993 (COSTA \& al., 1993: 58, Table 5). 
Diagnostic TAXa: Arabis stenocarpa, Cheirolophus sempervirens, Helminthotheca comosa subsp. lusitanica, Prunella x intermedia, Stachys germanica subsp. cordigera.

Distribution: southwestern Iberian Peninsula (Spain and Portugal).

DiAGNOSIS: tall-herb woodland fringes on decalcified, neutral to slightly acid mesotrophic substrata, in the themomediterranean and low mesomediterranean belts of the southwestern Iberia; associated with the Quercion broteroi and the Oleo sylvestris-Quercion rotundifoliae (Quercetea ilicis) forest communities.

SYNTAXONOMY: RIVAS-MARTÍNEZ \& al. (2011: 258-259) interpreted the Origanion virentis (Origanetalia vulgaris, Trifolio-Geranietea) as an alliance uniting both silicicolous and basicolous fringe communities. This is at variance with the current classification principle adopted in the Trifolio-Geranietea, where the substrate is one of major drivers at the alliance level, as this is the case in the North, Central and southwestern Europe. The considerable floristic differences between the suballiances Origanenion virentis (on acidic silicicolous soils in the mesomediterranean to supramediterranean belts) and the Stachyo lusitanicae-Cheirolophenion sempervirentis Capelo 1996 (on basic decalcified, neutral to slightly acid mesotrophic substrates in the thermomediterranean and low mesomediterranean belts) warrant recognition of the latter as an alliance in its own right.

At present, the following associations are included in the Stachyo lusitanicaeCheirolophion sempervirentis:

Bartsio asperae-Origanetum virentis Lopes, P. Gomes et Ladero 2008

Leucanthemo sylvatici-Cheirolophetum sempervirentis Costa et al. 1993

Origano virentis-Leucanthemetum sylvatici Pereira 2009

Picrido algarbiensis-Cheirolophetum sempervientis P. Gomes et Ferreira 2005

Senecio lopezii-Cheirolophetum sempervirentis Capelo 1996

Stachyo lusitanicae-Origanetum virentis (Capelo 1996) Capelo et Costa in Costa et al. 2002

\section{A NEW ORDER OF THE FRINGE VEGETATION FROM THE CANARY ISLANDS AND MADEIRA \\ (by Jorge Capelo \& Ladislav Mucina)}

\section{Ranunculo cortusifolii-Geranietalia reuteri Capelo et Mucina ordo nov. hoc loco (Trifolio-Geranietea)}

NAME-GIVING SPECIES: Geranium reuteri, Ranunculus cortusifolius.

Holotypus: Ranunculo cortusifolii-Geranion canariensis Rivas-Martínez, Wildpret, Del Arco, O. Rodríguez, Pérez de Paz, García Gallo, T.E. Díaz et Fernández-González 1993 (RIvAsMARTíNEZ \& al., 1993: Itinera Geobot. 7: 225). DiAgnostiC TAXA: Dactylorhiza foliosa, Geranium palmatum, G. reuteri, Myosotis latifolia, Pericallis appendiculata, P. aurita, P. cruenta, P. echinata, P. tussilaginis, Pimpinella dendrotragium, Ranunculus cortusifolius, Rumex maderensis, Scrophularia smithii, Teucrium francoi, Viola paradoxa.

Distribution: Canary Islands (Spain) and Madeira (Portugal).

Diagnosis: tall-herb fringe communities of Canary-Madeirean laurel forests (PrunoLauretea).

SYNTAXONOMY: The floristic composition of the Canary-Madeirean forest fringe communities is floristically (and obviously also biogeographically due to the high regional/local endemism) very different from the fringe communities of the continental Europe. According to the original proposal by RivAs-MARTínez \& al. (1993: 225-227), there are only Brachypodium sylvaticum, Carex divulsa, C. muricata subsp. pairae, Clinopodium menthifolium subsp. methifolium, C. vulgare subsp. arundanum and Origanum vulgare subsp. virens which would be linking the Canary-Madeirean fringe communities at class and order levels (Origanetalia vulgaris, Trifolio-Geranietea) with the continental European fringe syntaxa. In order to emphasize the special position of the Canary-Madeirean fringe communities, we introduce here a new ordo - the Ranunculo cortusifolii-Geranietalia reuteri and designate the sole alliance thus far 
recognised on both archipelagos - the Ranunculo cortusifolii-Geranion canariensis Rivas-Martínez et al. 1993 as the holotype of the new ordo. The character-species of the new ordo are identical to those of the type alliance as proposed in the protologue, adding those from COSTA \& al. (2004; see also RIVAS-MARTínEZ \& al. 2002). The inclusion of forest fringes of the Azores archipelago (Pericallion malvifoliae $\mathrm{F}$. Prieto, Dias et Aguiar in F. Prieto, Aguiar et Dias 2012) in this order could also be considered as plausible. Nevertheless, as it is in the scope of a different forest vegetation class (Lauro azoricae-Juniperetea brevifoliae), the only floristic link being Ranunculus cortusifolius and the greater floristic affinity is with Azorean grassland Tolpido-Holcetea rigidi, the inclusion of Azorean fringe communities in the new order remains only provisory.

\section{ON THE PRIORITY OF THE NAME}

SCORZONERETALIA VILLOSAE FOR THE

MESOXEROPHYTIC EUROPEAN

GRASSLANDS

(by Massimo Terzi \& Romeo Di Pietro)

\section{Scorzoneretalia villosae Kovačević 1959}

(Festuco-Brometea)

SYNONYMS: Brometalia erecti W. Koch 1926 nom. amb. rejic. prop. (ICPN art. 36); Scorzonero villosae-Chrysopogonetalia grylli Horvatić et Horvat in Horvatić 1963 (syntax. syn.); Brachypodio-Chrysopogonetalia (Horvatić 1958) Boşcaiu 1972 nom. inval. (ICPN art. 3m; Remark 1, ICPN art. 27); Scorzoneretalia villosae Horvatić 1973 nom. illeg. (ICPN art. 31); Scorzoneretalia villosae Horvatić 1975 nom. illeg. (ICPN art. 31).

HoLOTYPus: Scorzonerion villosae Horvatić ex Kovačević 1959 (KovAČEvić, 1959: Godišnjak Biološkog Instituta Univerziteta u Sarajevu 1-2: 3-46).

The meso-xerophytic alliances of the Festuco-Brometea, previously classified in different orders, have recently been combined into a single European mesophytic order, carrying the validly published name Brometalia erecti $\mathrm{W}$. Koch 1926 (Dengler \& al., 2003; Mucina \& $a l ., 2009)$. This name was proposed for rejection as nomen ambiguum since it has often been used (mostly accompanied the erroneous author citation 'Braun-Blanquet 1936') in a sense that excludes its nomenclatural type (DENGLER \& al., 2006). It has been further proposed (see Dengler \& al., 2003; Mucina \& al., 2009) that this rejected name be substituted by the Brachypodietalia pinnati Korneck 1974.

A recent revision of the Scorzoneretalia villosae Kovačević 1959 (TERZI, 2015) stressed some similarities between the mesophilous associations classified within the Scorzonerion villosae Horvatić ex Kovačević 1959 and the Brachypodietalia pinnati. The Scorzonerion villosae is the nomenclatural type of the Scorzoneretalia villosae and of its mesophilous suborder Scorzonerenalia villosae Terzi 2015. The revision has also documented that the original diagnosis of the Scorzonero villosaeDanthonietum calycinae Kovačević 1959, i.e. the type association of the Scorzonerion villosae (here including also the Hypochoeridion maculatae Horvatic ex Terzi 2011), was recorded in the area of Bosanski Petrovac (BosniaHerzegovina). This association, together with other mesophilous units of the same alliance, turned out to be similar to other Balkan mesoxerophytic syntaxa originally classified in the Bromion erecti and the DanthonioBrachypodion Boşcaiu 1972. Many authors (e.g. BoşCAIU, 1972; IliJanić \& al., 1972; Apostolova \& al., 2014; Terzi, 2015) discussed this similarity as well. BoşCAIU (1972) classified the Illyrian Scorzonerion villosae and the Romanian Danthonio-Brachypodion in the same order, the Brachypodio-Chrysopogonetalia (Horvatić, 1958) Boşcaiu 1972 nom. inval. (SANDA \& al., 2008; Terzi, 2015). The order suggested by BoşCAIU (1972) was nomenclaturally and syntaxonomically similar to the concept of Scorzoneretalia villosae. In fact HoRvatić (1958) included the Scorzonerion villosae in the original diagnosis of the Brachypodio-Chrysopogonetea and the same 
alliance was subsequently included by HoRvATIĆ (1963) in the Scorzonero-Chrysopogonetalia or in the Scorzoneretalia villosae (KovAČEvić, 1959; Horvatić, 1973). On the other hand, Dengler \& al. (2012) considered the Brachypodio-Danthonion to be a syntaxonomical synonym of the Cirsio-Brachypodion (the nomenclatural type of the Brachypodietalia pinnati) and included the latter in the Brachypodietalia pinnati. It is evident, therefore, that the mesophilous wing of the Scorzoneretalia villosae (Scorzonerion villosae) and the Brachypodietalia pinnati exhibit a significant degree of similarity.

Many species of the Scorzonerion villosae, including some of its diagnostic species, are shared with the Brachypodietalia pinnati (see for instance Dengler \& al., 2012; PedashenKo \& al., 2013; TerZI, 2015: Online Supplement 2) and therefore, following the idea of maintaining just one single European mesoxerophytic order, the alliance Scorzonerion villosae should be classified within the latter order. As a consequence, two syntaxa of the same rank (Scorzoneretalia villosae and Brachypodietalia pinnati) become united and either the earliest name, the Scorzoneretalia villosae, should be retained as the name of the resulting syntaxon (see the Introduction in WeBER \& al., 2000 and the ICPN art. 52), or the Brachypodietalia pinnati should be conserved.

The name Scorzoneretalia villosae, using the erroneous author citations 'HoRvATIĆ 1973' or 'Horvatić 1975', has been used in many syntaxonomic studies (e.g. HoRvatić, 1973, 1975; Poldini, 1989, 1995; PoldinI \& Kaligarič, 1997; SELIŠKAR, 1998; REDŽIĆ, 1999; REDŽIĆ \& $a l ., 2013$; Pignatti \& Pignatti, 2014); it is also used in the latest version of the Interpretation Manual of the European Union Habitats (European Commission, 2013). Following the proposal by HoRvatić (1973), the name Scorzoneretalia villosae has been used to designate the meso-xerophytic syntaxa of the Western Balkans and the southeastern Prealps. It has also been compared to the more xerothermic Koelerietalia splendentis Horvatić 1973 from the same region. Indeed the Scorzoneretalia vil- losae became a well-known and frequently accepted name. On the contrary, the Brachypodietalia pinnati has been largely interpreted as a synonym of the Brometalia erecti or, more rarely, of the Festucetalia valesiacae. It has also been completely ignored as is the case of many crucial syntaxonomic studies both at the European and national levels (e.g. ROYER, 1991; DoniŢă \& al., 1992; KolbeK \& MuCINA, 1993; Biondi \& al., 1995; Theurillat \& al., 1995; ChYtRÝ \& al., 2007 etc.), up to nearly a decade ago when the name was in some papers proposed as nomen conservandum.

Any further nomenclature steps (including either conservation of the Brachypodietalia pinnati against the Scorzoneretalia villosae or the conservation of the Scorzoneretalia villosae as prior name) could be taken only if it is shown beyond any doubt that the Scorzoneretalia villosae and Brachypodietalia pinnati are considered syntaxonomically identical (through the shared nomenclature type). In fact the wide geographical distance that separates the core distribution areas of the latter two orders (western regions of Central Europe for the Cirsio pannonici-Seslerietum caeruleae Klika 1933 as the nomenclature type of the Cirsio-Brachypodion and the Western Bosnia-Herzegovina for the Danthonio-Scorzoneretum Kovačević 1959 as the nomenclature type of the Scorzonerion villosae) would leave open the possibility that Scorzoneretalia villosae and Brachypodietalia pinnati are classified as two geographically orders in their own right.

\section{ON THE LEGITIMACY OF THE NAME BRACHYPODIO-BROMETALIA}

(by Romeo Di Pietro, Massimo Terzi \& Jean Paul-Theurillat)

The name 'Brachypodio-Brometalia ord. nov.' was proposed by BARBERO \& LOISEL (1972: 95; the date of publication of the first issue of volume 28 of the "Anales» is 1972 , not 1971, as reported in the footnote of the first page). The new order was proposed to distinguish the dry grasslands under Mediterranean 
influence from those of Central Europe. In BARBERO \& LOISEL (1972), the order Brachypodio-Brometalia was divided into two new sub-orders. (1) The 'S/O - AstragaloFestucetalia sub-ord. nov.' that included only the Festuco-Bromion Barbero et Loisel 1972 and which corresponds to dry grasslands syndynamically linked to the potential forest vegetation of the Querco-Fagetea and the Quercetea pubescentis, and (2) the ' $\mathrm{S} / \mathrm{O}$ - Brachypodietalia phoenicoidis (Br.-Bl. 1931) Mol. 1934', representative of dry grasslands syndynamically associated with the Quercetalia ilicis. However, the inclusion of the suborder Brachypodienalia phoenicoidis means the inclusion of the type of the 'Brachypodietalia phoenicoidis Br.-Bl. ex Molinier 1934' (ICPN art. 27) in the new order Brachypodio-Brometalia through an unambiguous bibliographical reference to MOLINIER (1934). Therefore, the new name 'BrachypodioBrometalia Barbero et Loisel 1972' is an illegitimate nomen superfluum for the name 'Brachypodietalia phoenicoidis Br.-Bl. ex Molinier 1934' (ICPN art. 29c).

VALIDATION AND SYNTAXONOMICAL DISCUSSION ON THE CIRSIO-NARDION, A MISUNDERSTOOD SILICICOLOUS ALLIANCE OF THE SOUTHERN ITALY (by Romeo Di Pietro \& Jean-Paul Theurillat)

Cirsio vallis-demoni-Nardion strictae Giacomini et Gentile ex Di Pietro et Theurillat all. nov. hoc loco

(Nardetalia strictae, Nardetea strictae)

SynONYMS: Cirsio-Nardion Giacomini et Gentile 1961 nom. inval. (ICPN arts. 2b, 8); Cirsio-Nardion Giacomini et Gentile 1966 nom. inval. (ICPN arts. 2b, 8); Potentillion calabrae de Foucault 1994 nom. inval. (ICPN art. 5).

NAME-GIVING TAXA: Cirsium vallis-demoni, Nardus stricta.

Holotypus (hoc loco): Luzulo multifloraeNardetum strictae Giacomini et Gentile ex Bonin 1978 (BonIN, 1978: 132).

Diagnostic taXa: Armeria brutia, Avenula praetutiana subsp. rigida, Centaurea sarfattiana, Cirsium vallis-demoni, Genista silana, Luzula calabra, Potentilla calabra, Viola aethnensis subsp. messanensis.

DiAGNOSIs: acidophilous grasslands on siliceous substrates dominated by Nardus stricta, developed in the montane belt of the south central Calabria (Southern Italy).

Distribution: Massifs of Sila, Serre Calabre and Aspromonte (Calabria, Italy).

GIACOMINI \& GENTILE (1961: 56-58) described two associations - the 'HypochaeridoPotentilletum calabricae' and the 'Luzulo multiforae-Nardetum strictae' - and classified them into a new alliance, the Cirsio-Nardion, with Cirsium vallis-demoni, Nardus stricta and Ranunculus thomasii as the character-species. However, no relevés were provided, nor was a reference to published relevés for the associations. Therefore, lacking a sufficient diagnosis, the name 'Cirsio-Nardion' is invalidly published (ICPN arts. 2b, 8). Five years later, Giacomini \& Gentile (1966: 136-137) proposed the same scheme in another paper, repeating the original text of their previous paper of 1961, however providing a synoptic table. The alliance 'Cirsio-Nardion' again contains the same (see above) two associations - the 'Luzulo-Nardetum' (with two subassociations) and the 'Hypochaerido-Potentilletum calabrae'. In the synoptic table, the 'Luzulo-Nardetum genistetosum' has ten species listed for five relevés. Although the constant species appear to be listed (five species with a constancy of V), the species with constancy of III are quite probably missing (only one species listed), hence the requirements of the ICPN art. 7 were not fulfilled. The 'Luzulo-Nardetum agrostietosum' has nine species listed for 11 relevés. The constant and the frequent species appear to be listed (three species with a constancy of $\mathrm{V}$ and two with a constancy of IV), but the medium frequency (II and III) species are almost missing with two species with a constancy of III and none of II, hence the the requirements of the ICPN art. 7 were not fulfilled. The Hypochaerido-Potentilletum calabrae with just seven species listed, of which 
none having a constancy of IV in 14 relevés and two species having a constancy of I, does not meet the criteria of the ICPN art. 7. Moreover, the characteristic species of the highest syntaxonomical ranks (class and order), as well as the companion species, are completely missing. Those three synoptic columns presented in the table do not meet the requirements of the article 7 of ICPN for a sufficient diagnosis of an association in case a synoptic table is available (to provide at a minimum the species with a constancy higher than 20\%). GiaCOMINI \& GentiLE (1961: 136) further stated that these associations «will be described soon in a larger, floristic and ecological work» (translated from French). Therefore, the two associations included by Giacomini \& Gentile (1961) in the 'CirsioNardion' are deemed invalidly published (ICPN arts. 2b, 7) and, as a consequence, the name 'Cirsio-Nardion' is lacking a sufficient diagnosis.

Without having been validated, the name 'Cirsio-Nardion' was recently proposed again as a good syntaxonomical concept for the Apennine Peninsula by UBALDI (2011: 74) and De Foucault (2012: 251). In particular, de Foucault (2012) designated the name 'Luzulo multiflorae-Nardetum Giacomini \& Gentile 1966' as the lectotypus of the 'Cirsio vallis demonis-Nardion Giacomini \& Gentile 1966'. This lectotypification is superfluous as the name of the alliance is invalid. It is relevant, however, that in his paper de Foucault commented on the synoptic relevés in Giacomini \& Gentile (1966) of the associations 'Luzulo multifloraeNardetum' and 'Hypochaerido-Potentilletum' as being "doubtless incomplete» making him «to renounce to include a synoptic column» in the general table of his paper.

Earlier, De Foucault (1994: 441) proposed the name 'Potentillion calabrae (BoNIN 1978) all. nov.' (recte: Potentillion calabrae de Foucault 1994) to accommodate syntaxonomically the grasslands supported by siliceous substrates of the Southern Italy. This alliances contained two associations, such as the 'Luzulo multiflorae-Nardetum strictae Giacomini \& Gentile 1966' and the 'Foeniculo-Festucetum spadiceae (Giacomini \& Gentile 1966) Bonin
1978'. De Foucault (1994) selected the name 'Luzulo multiflorae-Nardetum strictae Giacomini \& Gentile 1966' as the type of his new alliance. However, independently of the invalidity of the name 'Luzulo multifloraeNardetum strictae Giacomini \& Gentile 1966', there was neither a direct nor an indirect bibliographical reference to Giacomini \& Gentile (1966) in the de Foucault's paper. De FoucaulT (1.c.) referred to Bonin (1978) for the 'Luzulo multiflorae-Nardetum strictae Giacomini \& Gentile 1966'. Although BonIN (1978: 130-136) identified the 'Luzulo multiflorae-Nardetum strictae Giacomini \& Gentile 1966' in the Sila Massif and provided an incidental validation of the latter name with a complete phytosociological table composed of 14 relevés containing 63 species to be included in the alliance Ranunculo-Nardion Bonin 1972, there is no bibliographical reference to Giacomini \& Gentile (1966) in Bonin (1978), but only a reference to 'Giacomini \& GentiLe (1962)' [recte: 1961] where the 'Luzulo-Nardetum 'was invalidly published (see above). As the incidentally validated name Luzulo multiflorae-Nardetum strictae Giacomini et Gentile ex Bonin 1978 is not the name designated by De Foucault for the type, a valid type is missing for the "Potentillion calabrae de Foucault 1994' and thus the name remains invalidly published (ICPN art. 5).

Since the names 'Cirsio vallis-demoniNardion strictae' and 'Potentillion calabrae' were invalidly published, we validate here the name Cirsio vallis-demoni-Nardion strictae by selecting the Luzulo multiflorae-Nardetum strictae Giacomini et Gentile ex Bonin 1978 as the nomenclature type of the alliance.

The idea of an alliance endemic of the siliceous substrates for the south-central Calabria is in accordance with the peculiar biogeographical and ceonological features of this area. The Nardus stricta grasslands of the massifs of Sila, Serre Calabre and Aspromonte are distinguished from the rest of the acidophilous grasslands of the Southern Apennines due to their strong endemic component (BERNARDO \& al., 1991; BRULlo \& al., 2004, 2007). Taxa such as Anthemis cretica subsp. calabrica, Armeria 
brutia, Helictochloa versicolor subsp. praetutiana, Carlina nebrodensis, Centaurea poeltiana, C. sarfattiana, Cirsium vallis-demoni, and Viola aethnensis subsp. messanensis do not occur in the adjacent limestone massifs of Pollino and Orsomarso and they are restricted to the siliceous mountains of Calabria.

The alliance Cirsio vallis-demoni-Nardion is widespread throughout the Sila Massif, the Serre Calabre and the Aspromonte. It does not occur in Sicily where BRULLO \& GRILlo (1978) classified the montane, mesic acidophilous grasslands of the Nebrodi Mountains (Northern Sicily) in the Molinio-Arrhenatheretea and proposed a new order - the Cirsietalia vallis-demoni. The possible syntaxonomical synonymy between the Cirsio-Nardion and Ranunculo-Nardion, as suggested by BonIn (1978), is hardly plausible. The Cirsio-Nardion is restricted to siliceous substrates of the montane belt, in contact with the potential Pinus nigra subsp. calabrica or Fagus sylvatica forests. The RanunculoNardion occurs on limestone substrates of the subalpine belt of the Southern Apennines as primary grasslands or in places also as secondary grasslands, syndynamically linked to the potential dwarf-shrub communities of the region. DE FouCAult (1994) classified the RanunculoNardion in the Trifolietalia parnassi Quézel 1964, supposed to occur at high elevations of the Apennines and in the Southern Greece. This suggestion, however, lacks solid floristic and ecological grounding; the Trifolietalia parnassi Quézel 1964 do not occur on the Apennine Peninsula.

ABbATE \& al. (1984) considered the Nardus stricta mat-grass (Nardetea strictae) as the final dynamical stage of all the meso-acidophilous pastures of the Sila Massif. In contrast, BRULLO \& al. $(2001,2004,2005)$ have not considered the Nardetea strictae as occurring in the southcentral Calabria where they included the majority of the mesic acidophilous montane grasslands in the Anthemidetalia calabricae (Cerastio-Carlinetea nebrodensis) which includes the Sicilian and Calabrian orophilous cushion-like vegetation. They classified the remainder of the grasslands in the Cirsietalia vallis-demoni and the Holoschoenetalia (Molinio-Arrhenatheretea).

We designate the lectotypus hoc loco for the name Luzulo multiflorae-Nardetum strictae Giacomini et Gentile ex Bonin 1978 by selecting the relevé 655 of Table 12 in BonIn (1978). The remaining nomenclatural act in the context of the Cirsio-Nardion should be the validation of the other association proposed by GIACOMINI \& Gentile (1961), the 'HypochaeridoPotentilletum calabricae'. In this connection, BRULLO \& al. (2004: 473) proposed the name 'Armerio brutiae-Potentilletum calabrae Brullo, Gangale et Uzunov ass. nov.', but this name was invalidly published due to nomenclatural technicality (using the English term 'holotype' instead of the Latin 'holotypus' as required by the ICPN art. 5). The Hypochaerido-Potentilletum calabricae was considered a synonym of the 'Armerio brutiae-Potentilletum calabrae'. This association was validated later in Brullo \& al. (2005: 125) who described two subassociations, such as the 'potentilletosum calabrae' (= typicum) that would correspond to the 'HypochaeridoPotentilletum calabricae', and the 'seselietosum peucedanoidis'. The latter subassociation includes (in the synonymy) the name 'FoeniculoFestucetum spadiceae Giacomini et Gentile 1961 ex Bonin 1978' considered as invalidly published by claiming that the Bonin's $\mathrm{PhD}$ thesis was not published as printed material (see ICPN art. 1). As already mentioned by Di PIETRo (2011), the $\mathrm{PhD}$ thesis of BonIN (1978) is an effective publication. Therefore the Foeniculo-Festucetum spadiceae Giacomini et Gentile ex Bonin 1978 is a valid name. As a consequence, the name Armerio brutiae-Potentilletum calabrae Brullo, Gangale et Uzunov ex Brullo in Brullo, Cormaci, Giusso del Galdo, Guarino, Minissale, Siracusa et Spampinato 2005 is a superfluous, illegitimate name (ICPN art. 29c). The name 'FoeniculoFestucetum spadiceae' was proposed by Giacomini \& Gentile (1961: 57; 1966: 136), who published this name invalidly for the same reasons mentioned above for the LuzuloNardetum and the 'Hypochaerido-Potentilletum' (ICPN arts. 2b, 7). The name 'FoeniculoFestucetum spadiceae' has been validated inci- 
dentally later by Bonin (1978: 135-139, Table 15) who presented a phytosociological table composed of five relevés and 56 species. To our knowledge, the name Foeniculo-Festucetum spadiceae Giacomini et Gentile ex Bonin 1978 has not been typified yet and therefore we designate here the lectotypus hoc loco for the Foeniculo-Festucetum spadiceae by selecting the relevé 632 in the Table 15 in Bonin (1978). Bonin included this association in his RanunculoNardion. In agreement with DE FoucAult (1994), we suggest that it belongs to the CirsioNardion.

ON THE NOMENCLATURE OF THE

NAMES NARDETEA STRICTAE,

CALLUNO-NARDETEA, NARDETALIA

STRICTAE AND NARDO-GALION SAXATILIS

(by Jean-Paul Theurillat)

Nardetea strictae Rivas Goday et Borja Carbonell in Rivas Goday et Mayor López 1966 nom. conserv. propos.

For some authors (see TÜXEN, 1974), it was OBERDORFER (1949) in the first edition of his Pflanzensoziologische Exkursionsflora who coined the name 'Nardetea'. However, the name 'Nardetea' does not appear in the Oberdorfer's flora where only the German word 'Nardeten' (a plural to denominate all the meadows dominated by Nardus stricta) was used. On p. 16, OBERDORFER (1.c.) suggested a «class of nutrient-poor swards and pastures on acid soils» (orig.: «Klasse der bodensauren Magerrasen u. Magerweiden»), with the order Nardetalia retained as provisional, but the class was not named specifically. Therefore, the name 'Nardetea Oberdorfer 1949' is a phantom.

The name 'Nardetea strictae' was published for the first time in RIVAS GODAY \& BORJA CARBonell (1961) both as a class (pp. 10, 178, $218,220,225)$ and as a subclass (p. 218). From the syntaxonomical structure of the whole paper, it is clear that the syntaxon designated under the name 'Nardetea strictae' should be considered at the class level. Indeed, on p. 218, the authors refer to the 'Clase XV. - (Subclas.) Nardetea (Oberd., Prsg. 1949)'. In similar cases in the same paper, e.g. 'Chenopodio-Stellarietea' on p. 275, the reverse connotation was used when a name should be retained at the subclass level: (e.g. 'Subclase (clase) XX. - Chenopodio-Stellarietea Riv. God. 1955'). Contrary to the opinion of DE FouCAulT (2012: 241), the fact that the authors stated on $p$. 218: «To consider the order Nardetalia Prsg. 1949 as an independent subclass is due to the fact that the Calluno-Ulicetalia Tx. 1937 is not present in our region,...» (orig.: «El considerar al orden Nardetalia Prsg. 1949 como subclase independiente, es debido a que la Calluno-Ulicetalia Tx. 1937 no está presente en nuestra región, ...»), is not a procedure at variance with the Code and it is in accordance with the ICPN art. 3e. However, either at the rank of class or subclass, the name 'Nardetea' was invalidly published (ICPN art. $2 \mathrm{~b})$. Indeed, there is no bibliographical reference to Preising (1949) for the order 'Nardetalia Prsg. 1949', the only order of the original diagnosis of the name. Equally the order 'Nardetalia' was invalidly published in RIVAS GODAY \& BORJA CARBONELl (1961) with the unique alliance 'Nardo-Galion saxatilis Prsg. 1949' that contains a single association, the 'Nardetum gudaricum'. Although the latter name was validly published, the relevés of the association do not include the name-giving taxon Galium saxatile making the name 'Nardo-Galion saxatilis' invalidly published (ICPN art. 3f). Therefore, both the class 'Nardetea Rivas Goday \& Borja Carbonell 1961' and the subclass 'Nardetea Rivas Goday \& Borja Carbonell 1961' (recte: Nardenea Rivas Goday et Borja Carbonell 1961) were invalidly published because both names were lacking a sufficient diagnosis (ICPN art. 2b).

In Rivas GodAY \& Rivas-Martínez (1963), the name 'Nardetea' corresponding to a class on p. 148 was invalidly published. The original diagnosis of the class contains two orders: (a) the 'Nardetalia Prsg, 1943' and (b) the 'UdoNardetalia Quezel, 1953' (pp. 148-149).

(a) In the order 'Nardetalia' three alliances were mentioned: 'Nardo-Galion saxatilis Prsg, 1943', 'Nardo-Trifolion alpini Prsg, 1949' and 'Campanulo-Nardion Riv. Mart., 1960'. All 
three alliances were not valid elements of the diagnosis of the order according to ICPN art. 8. For the 'Nardo-Galion saxatilis' and the 'Nardo-Trifolion alpini', there is no reference to 'Preising (1943)' or to 'Preising (1949)', respectively. For the 'Campanulo-Nardion', there is no reference to 'Rivas-Martínez (1960)'. Even if we consider that the unique, validly published association 'Nardetum gudaricum Riv. God. et Borja 1961' listed in the suballiance 'IdubedoNardion' of the 'Nardo-Galion saxatilis' would be implicitly an element of the latter alliance, one could argue that there is no unambiguous reference according to ICPN art. 2b, Note 3, to Rivas Goday \& Borja Carbonell (1961). The name of the journal, the volume and the pages are missing, and only the title of the paper was given. However, even if we admit that the bibliographical indication was sufficient at that time, the name-giving taxon Galium saxatile is missing in the 'Nardetum gudaricum' (ICPN art. 3f), as in RIVAS GODAY \& BORJA CARBONELl (1961).

(b) The order 'Udo-Nardetalia Quezel, 1953' contains the alliance 'Plantaginion thalackeri Quezel, 1953'. Although a bibliographical reference is given to QuÉZEL (1953) in the «Bibliografía» on p. 264 («Contribution á l'Etude phytosociologique et Geobotanique de la Sierra Nevada»), the reference is not an unambiguous reference according to ICPN art. $2 b$, Note 3 since the name of the journal, the volume, and the pages are missing. Since the Quézel's paper is not a book publication, at least the journal should have been mentioned for to create an unambiguous reference. Hence, independently of the fact that the name 'Udo-Nardetalia' was validly published in Quézel (1953), the order 'UdoNardetalia' was not a valid element of the original diagnosis of the class 'Nardetea' in RIVAS GODAY \& RivAS-MARTínEZ (1963) according to ICPN art. 8. Therefore, the name 'Nardetea Rivas Goday in Rivas Goday et Rivas-Martínez 1963' was invalidly published due to the absence of a sufficient diagnosis (ICPN art. 2b) because both the orders 'Nardetalia' and 'Udo-Nardetalia' are lacking a sufficient diagnosis or a reference to a published one.
In RIVAS-GODAY \& MAYOR LÓPEZ (1966), the name 'Nardetea Riv. God. et Borja, 1961' was accepted as a class on p. 396, with the single order 'Nardetalia (Oberd.) Preising, 1949' that included the 'Campanulo-Nardion Riv. Mart., 1959'. In the bibliography, there is no reference to PreISING (1949), nor a reference to a paper by RivasMartínez published in 1959. However, on p. 354, the authors explicitly mentioned the CampanuloNardion for the Cordillera Central with a reference to Rivas-Martínez given as «(Riv. Martz.) (20)», the number 20 corresponding in the bibliography to RIVAS-MARTíNEZ (1963) [recte: 1964] where one would find on p. 124 the name 'Campanulo-Nardion Rivas Mart. 1959' that is validly published with two validly published associations - the Campanulo-Festucetum violaceae and Luzulo-Juncetum ellmanii (the correct citation of the alliance name should read: Campanulo-Nardion Rivas-Martínez 1964). Therefore, there is a sufficient diagnosis for the order's name Nardetalia that is, incidentaly, a later, illegitimate homonym of Preising's name in 1950 (ICPN art. 31); the correct citation of this later homonym is 'Nardetalia Preising ex Rivas Goday et Mayor López 1966 nom. illeg.' Although illegitimate, the name 'Nardetalia' was validly published in RIVAS GODAY \& MAYOR LÓPEZ (1966) and thus provides a sufficient diagnosis for the name of the class. Following the Recommendation $10 \mathrm{C}$ of the ICPN, the correct citation of the name should read: Nardetea strictae Rivas Goday et Borja Carbonell in Rivas Goday et Mayor López 1966. However, this name is a later syntaxonomic synonym of the NardoCallunetea published by PREISING (1950).

Since the name Nardetea strictae is well established in phytosociological literature, we propose to conserve the Nardetea strictae against the earlier name Nardo-Callunetea Preising 1950.

\section{Nardo-Callunetea Preising 1950}

In his paper about the secondary, acidic low heaths and oligotrophic swards at low elevation, PREISING (1949) proposed to group these two for- 
mations, for Central Europe under an Atlantic climatic influence, in a single class - the 'NardoCallunetea' on the basis of their strong floristic affinities resulting from a common syngenesis. Syntaxonomically, each formation corresponds to an order - the 'Calluno-Ulicetalia' for the heaths, and the 'Nardetalia' for the swards. As for the sufficient diagnosis, the Nardo-Callunetea Preising 1949 would be a valid name. However, the first volume of the Mitteilungen der Floristisch-soziologischen Arbeitsgemeinschaft N.F., where the paper has been 'published' does not fulfill the conditions of the ICPN art. 1. It is not a printed matter and it is hard even for a specialist to identify the production process used. Beside the technical aspect, at least three hints support the view that the volume 1 of the Mitteilungen der Floristisch-soziologischen Arbeitsgemeinschaft N.F. is not a printed matter: (1) the original publication is in A4 format; (2) the volume was hardly distributed outside the society (Arbeitsgemeinschaft); for instance it is missing in the extensive Braun-Blanquet Library in Bailleul (France), even in the form of a reprint, and finally and perhaps most importantly, (3) the volume was reprinted in 1955 with a new pagination for a better distribution, however using probably the same technique of production.

PREISING (1950) described several associations from the northwestern Germany dominated by Nardus stricta, grouping them into a single alliance - the Nardo-Galion saxatilis within the order Nardetalia. Both names were validly published (see below). The order was classified in the Nardo-Callunetea that is referred to his previous work (PreISING, 1949). In so doing, Preising provided a sufficient diagnosis for the valid publication of the name Nardo-Callunetea. However, nomenclaturaly the class contains only swards and no more the low heaths of the CallunoUlicetalia. Therefore, the name NardoCallunetea Preising 1950 is an earlier name (heterotypic synonym) for the name Nardetea strictae Rivas Goday et Borja Carbonell in Rivas Goday et Mayor López 1966. However, since the Preising's name has nearly always been used in the broad sense as intended by its author, it is proposed to conserve the name Nardetea strictae for the class of the secondary mat-grass swards on nutrient-poor, acidic soils.

\section{Nardetalia strictae Oberdorfer ex Preising 1950 (Nardetea strictae)}

The name 'Nardetalia' was validly published in Table 1 in PREISING (1950). The original diagnosis of the order contains three validly published associations ('Nardo-Gentianetum pneumanthis Prsg. 1950', 'Planthantera robustaNardus stricta-Ass. Prsg. 1950', 'Botrychium lunaria-Polygala vulgaris-Ass. Prsg. 1950'). In his paper, Preising has not attributed the order's name to Oberdorfer. Therefore, the correct citation of the order reads: Nardetalia strictae Preising 1950 (adding the specific epithet, following the ICPN Recommendation 10C).

Remark on the name 'Nardetalia' in PREISING (1949): As for the sufficient original diagnosis, the name 'Nardetalia' was validly published on p. 88 in Preising (1949; p. 18 in reprint of 1955). Indeed, Preising retained explicitly the provisional name 'Nardetalia' published by OBERDORFER (1949: 16) to be included in his new class 'NardoCallunetea'. The original diagnosis of the order contains three alliances: 'Nardo-Galion', 'Trifolio alpini-Nardion', 'Nardion boreale'. Among these three alliances, only the 'Nardo-Galion' was validly published in the same paper. The 'TrifolioNardion' was invalidly published because no association had been explicitly attributed to this new alliance that corresponds pro parte to the 'Nardion Braun-Blanquet 1926' (ICPN art. 2b); the 'Nardion boreale' is a provisional name (ICPN art. 3b). However, since the publication by PREISING (1949) is not considered 'printed matter' in the sense of ICPN art. 1 (see above: NardoCallunetea Preising 1949), the name 'Nardetalia Preising 1949’ was not effectively published.

\section{Nardo-Galion saxatilis Preising 1950 \\ (Nardetalia strictae, Nardetea strictae)}

As for the name 'Nardetalia', the name 'Nardo-Galion saxatilis' is validly published in 
Table 1 in Preising (1950), with the same three validly published associations mentioned above for the order. However, the name Nardo-Galion saxatilis is a later syntaxonomical synonym of the Violion caninae Schwickerath 1944.

Remark on the name 'Nardo-Galion saxatilis' in Preising (1949): The name 'Nardo-Galion saxatilis' was not effectively published (ICPN art. 1) in Preising (1949; see above: NardoCallunetea Preising 1950). Syntaxonomically, the Nardo-Galion is a nomenclatural synonym of the Violion caninae Schwickerath 1944, because Preising (1.c.) included in the 'NardoGalion' two associations that form the original diagnosis of the Violion caninae.

\section{NOMENCLATURAL NOTES ON THE PASPALO-HELEOCHLOETALIA \\ (by Jean-Paul Theurillat)}

The name 'Paspalo-Heleochloetalia Br.-B1. Ord. nova' was invalidly published on p. 70 in BRAUN-BLANQUET \& al. (1952) because there was no taxon belonging to the genus Heleochloa quoted in the original diagnosis of the order. In fact this order contains (as a valid element) only the alliance 'Paspalo-Agrostidion Br.-B1. all. nova' which was validly published with its unique association 'Paspaleto-Agrostidetum Br.-Bl. 1936' for which the reference was given in the bibliography of BRAUn-Blanquet \& al. (1952).

The other alliance ('Heleochloion Br.-Bl. all. nova prov. ) as well as its unique association ('Heleochloetum schoenoidis Br.-Bl. prov. ), mentioned in the order 'Paspalo-Heleochloetalia', are considered provisional (ICPN art. 3b). Because of the missing taxa of the genus Heleochloa in the original diagnosis of the association Paspalo-Agrostietum Br.-B1. in Br.-B1., Gajewski, Wraber et Walas 1936, the name Paspalo-Heleochloetalia Br.-B1. in Br.-B1., Roussine et Nègre 1952 was invalidly published (ICPN art. 3f).

The name 'Paspalo-Heleochloetalia Br.-B1. 1952 ' was validly published on p. 365 in RIVASGODAY (1956). The original diagnosis of the name contains the 'Paspalo-Agrostidion Br.-Bl.
1936' [recte: Paspalo-Agrostion Br.-Bl. 1952] and the 'Heleochloion Br.-B1. 1952'. The latter name was validly published on p. 366, with the association 'Heleochloeto-Fimbristyletum $\mathrm{Br}$. B1. et Rivas Goday, nova' containing both name giving taxa of the order (Paspalum distichum and Heleochloa schoenoides). The name 'Heleochloion', provisionally published by Braun-Blanquet in Braun-Blanquet \& al. (1952) is thus validated in RIvAS GODAY (1956). Hence, the correct citation for both the alliance and the order is Heleochloion Braun-Blanquet ex Rivas Goday 1956 and Paspalo-Heleochloetalia Br.-Bl. ex Rivas Goday 1956, respectively.

To our knowledge, the name PaspaloHeleochloetalia Br.-B1. ex Rivas Goday 1956 (RIVAS GodaY, 1956: 365) has not been typified yet. Therefore, I select here the name PaspaloAgrostion Br.-Bl. in Br.-Bl. et al. 1952 as the lectotypus hoc loco (BRAUN-BLANQUeT \& al., 1952: 71). The association Paspalo-Agrostietum Br.-Bl. 1936 is automatically the holotype of the name Paspalo-Agrostion Br.-Bl. in Br.-Bl. et al. 1952 (ICPN art. 18).

\section{NOMENCLATURE NOTES ON THE NAMES PLANTAGINI-CORYNEPHORION, CORYNEPHORO-PLANTAGINION, AGROSTIO CASTELLANAE-PLANTAGINION RADICATAE AND HIERACIO-PLANTAGINION (by Jean-Paul Theurillat)}

\section{Plantagini-Corynephorion Rivas Goday et Rivas-Mart. 1963 nom. inval. (ICPN art. 2b)}

In Rivas GodAy \& Rivas-MartínEZ (1963: 257), the alliance 'Plantago-Corynephorion nova' was listed in the synsystematic scheme as a nomen nudum (ICPN art. 2b). The correct citation of the invalidly published name is Plantagini-Corynephorion Rivas Goday et Rivas-Mart. 1963 nom. inval. (ICPN 2b).

In Rivas GodaY (1964) the alliance 'Plantago-Corynephorion Riv. God. et Riv. Mart. 1963' in the order 'Corynephoretalia' either does not appear to be adopted (ICPN art. $3 b)$ or appears as a synonym (ICPN art. 3a). The 
name was cited in the table of contents on p. XI after the alliance 'Corynephorion'. In the synsystematic scheme on p. 97, it is the only alliance listed for the order 'Corynephoretalia', but on p. 414, where the latter order was described, the alliance 'Corynephorion' appears to be retained and the 'al. PlantagoCorynephorion Riv. God et Riv. Martz., 1963' was listed as a synonym after a list of indicator species for the alliance 'Corynephorion Klika 1931'. Therefore, it appears that the name 'Plantago-Corynephorion' was not distinguished from the alliance Corynephorion. In addition, the name Plantagini-Corynephorion lacks an original diagnosis (ICPN art. 2b) with no association having been assigned to the alliance. On p. 415 only relevés of fragmentary nature were presented and attributed to the alliance Corynephorion. Therefore, no validation of the name Plantagini-Corynephorion Rivas Goday et Rivas-Mart. 1963 occurs in Rivas GodAY (1964).

\section{Corynephoro-Plantaginion radicatae Rivas Goday et Rivas-Mart. in Rivas-Mart. 1975 nom. inval.}

Rivas-MARTíneZ (1975: 1523) mentioned the alliance 'Corynephoro-Plantaginion radicatae Rivas Goday et Rivas-Martínez 1963 nom. inver. 'with the single association 'PlantaginiJasionetum sessiliflorae Rivas-Martínez ined.' . The latter name is a nomen nudum, due to lack of any bibliographical reference to a published relevé. Therefore, the alliance name lacks a sufficient diagnosis too and hence was invalidly published (ICPN art. 2b). The correct citation of the invalidly published name reads: PlantaginiCorynephorion Rivas Goday et Rivas-Mart. in Rivas-Mart. 1975 nom. inval. (ICPN art. 2b).

\section{Corynephoro-Plantaginion radicatae Rivas Goday et Rivas-Mart. ex G. López 1978}

In LóPEZ (1978) the name 'CorynephoroPlantaginion radicatae Rivas Goday \& Rivas-
Martínez 1963 ' was indicated in the syntaxonomic scheme on p. 601 for the class SedoScleranthetea, the order Sedo-Scleranthetalia. On p. 661, the association 'ScleranthoCorynephoretum Vigo 1968' was mentioned for the alliance, with an unambiguous bibliographical reference to VIGO I BONADA (1968) where the original diagnosis of the validly published association 'Sclerantho-Corynephoretum (comunicat de Plantago radicata i Corynephorus canescens Rivas i Borja 1961)' is considered to contain also three relevés published by RIVAS GODAY \& BORJA (1961: 224) for the 'comunicat' in addition to other three relevés published by VIGO I BONADA (1.c.) on p. 190. Therefore, the name 'Corynephoro-Plantaginion radicatae' was validly published in LóPEZ (1978) because the name-giving taxon Plantago radicata is present in those relevés of RIVAS GODAY \& BORJA (1961). Thus, the correct citation for the name reads: Corynephoro-Plantaginion radicatae Rivas Goday et Rivas-Mart. ex G. López 1978.

Remark: The original diagnosis of the name Sclerantho-Corynephoretum Vigo i Bonada 1968 contains both Scleranthus annuus and $S$. polycarpos, and it is not possible (hence not appropriate) to add a taxon epithet for the genus following ICPN Rec. 10C (but see RIVASMARTíNEZ \& al., 2011: 270, 'Sclerantho polycarpi-Corynephoretum canescentis').

\section{Corynephoro-Plantaginion radicatae sensu auct.}

RIVAS-MARTíNEZ \& al. (1984: 151-152) included a new and validly published association 'Sclerantho perennis-Plantaginetum radicatae as. nova' in the alliance 'Corynephoro-Plantaginion radicatae', together with the association Diantho merinoi-Plantaginetum radicatae that is attributed to 'Penas \& Díaz-González (1984) '. On p. 215, the authority for the alliance is given in the following form: 'Corynephoro-Plantaginion radicatae Rivas Goday et Rivas-Martínez in Penas et T.E. Díaz 1984'. However, the paper by PENAS \& DíAZ-GonZÁLeZ (1.c.) has not been published in 1984 but later in 1985. In RIVAS-MARTíNEZ \& al. 
(1984), the original diagnosis of the CorynephoroPlantaginion radicatae contains only the 'Sclerantho perennis-Plantaginetum radicatae' that is missing the name-giving taxon Corynephorus canescens in both relevés (ICPN art. 3f). Therefore, the name 'CorynephoroPlantaginion radicatae Rivas Goday et RivasMartínez in Penas et T.E. Díaz 1984' was not validly published incidentally in RIVAS-MARTíNEZ \& al. (1984).

PenAS \& DíAZ-GonzÁlez (1985) classified two validly published associations in the 'Corynephoro-Plantaginion radicatae Rivas Goday et Rivas-Martínez 1963 nom. invers. Rivas-Martínez 1975', namely the Diantho merinoi-Plantaginetum radicatae Penas et Díaz-González 1985 and the ScleranthoCorynephoretum Vigo 1968 (using a bibliographical reference to VIGO I BONADA, 1968). However, the invalid alliance name in RIVASMARTíneZ (1975) was not validated incidentally in Penas \& Díaz-González (1985) because it included two associations (ICPN art. 5).

\section{Hieracio castellani-Plantaginion radicatae Rivas-Mart. et Cantó 1987 and Jasiono sessili- florae-Koelerietalia crassipedis Rivas-Mart. et Cantó 1987}

RivaS-MARTínEZ \& CANTÓ (1987: 253-257) described the Hieracio castellani-Plantaginion radicatae, which became the type of the new order - the Jasiono sessiliforae-Koelerietalia crassipedis. The alliance contains two associations - the Hieracio castellani-Festucetum indigestae and the Thymo sylvestris-Plantaginetum radicatae, the latter being the type of the new alliance. The Jasiono sessiliforae-Koelerietalia crassipedis is classified in the Sedo-Scleranthetea.

\section{'Agrostio castellanae-Plantaginion radicatae Rivas Goday ex Rivas-Mart. et Fernández González 1991'}

This phantom name is rather a strange hybrid mismatch between two validly published names - the Agrostio castellanae-Stipion giganteae Rivas Goday ex Rivas-Mart. et Fernández-González 1991 and the Hieracio castellani-Plantaginion radicatae Rivas-Mart. et Cantó 1987.

\section{Syntaxonomic summary}

According to Rivas-MARTínez \& CANTÓ (1987), the alliance Hieracio castellaniPlantaginion radicatae corresponds syntaxonomically to the Corynephoro-Plantaginion sensu Rivas-Martínez (1975), Rivas-MartínEZ \& al. (1984) and PENAS \& DíAZ-GonZÁlez (1985). On the other hand, it differs from the PlantaginiCorynephorion sensu RIvas GODAY \& RivasMARTíneZ (1963) and the CorynephoroPlantaginion sensu G. LóPEZ (1978). This point of view was upheld later, e.g. in DíAZ-GonZÁLEZ \& FERNÁNDEZ PRIETo (1994). In RivAs-MartíneZ \& al. (2011), no synonymy was given any more. However, the association 'Sclerantho polycarpiCorynephoretum canescentis Rivas Goday et Borja ex Vigo 1968' [recte: ScleranthoCorynephoretum canescentis], which is the holotype of the original diagnosis of the alliance Corynephoro-Plantaginion Rivas Goday et Rivas-Mart. ex G. López 1978, is classified in the alliance Hieracio castellani-Plantaginion radicatae. In the same way, the alliances PlantaginiCorynephorion, Corynephoro-Plantaginion and Hieracio castellani-Plantaginion radicatae were initially included in the classes SedoScleranthetea or Corynephoretea, but later reclassified in the Festucetea indigestae (e.g. RIVASMARTíneZ \& al., 2001, 2011) as already done by Penas \& Díaz-GonzÁlez (1985). Therefore, these three alliances are syntaxonomic synonyms and the Corynephoro-Plantaginion radicatae Rivas Goday et Rivas-Mart. ex G. López 1978 is the earlier validly published name. In order to achieve stability, it is proposed to conserve the name in current use, the Hieracio castellaniPlantaginion radicatae Rivas-Mart. et Cantó 1987, a later syntaxonomical synonym of the name Corynephoro-Plantaginion Rivas Goday et Rivas-Mart. ex G. López 1978. 
The syntaxonomical synopsis of the syntaxa handled above:

Festucetea indigestae Rivas Goday et RivasMart. 1971

Jasiono sessiliflorae-Koelerietalia crassipedis Rivas-Mart. et Cantó 1987

Hieracio castellani-Plantaginion radicatae Rivas-Mart. et Cantó 1987 nom. conserv. propos.

Syn.: Plantagini-Corynephorion Rivas Goday et Rivas-Mart. 1963 nom. inval. (ICPN art. 2b)

Syn.: Corynephoro-Plantaginion radicatae Rivas Goday et Rivas-Mart. in Rivas-Martínez 1975 nom. inval. (ICPN art. 2b)

Syn.: Corynephoro-Plantaginion radicatae Rivas Goday et Rivas-Mart. ex G. López 1978

Syn.: Corynephoro-Plantaginion radicatae sensu Rivas-Mart. \& al. 1984 [sub: Corynephoro-Plantaginion radicatae Rivas Goday et Rivas-Mart. in Penas et T.E. Díaz 1985]

Syn.: Corynephoro-Plantaginion radicatae sensu Penas \& Díaz-González 1985 [sub: Corynephoro-Plantaginion radicatae Rivas Goday et Rivas-Mart. 1963 nom. invers. Rivas-Mart. 1975]

\section{NOTES ON A FORGOTTEN NAME: THE OLIGO-BROMION \\ (by Federico Fernández-González)}

The name Oligo-Bromion had appeared at several occasions in the Spanish phytosociological literature during the 1960s and 1970s, yet later on it has been forgotten and in fact has not been referred to again in the most recent syntaxonomical syntheses (e.g. RIVASMARTínEZ \& al., 2002, 2011). Here we trace the history and nomenclature status of the name in attempt to solve the nomenclatural and syntaxonomic intricacies surrounding this concept.

\section{Oligo-Bromion Rivas Goday \& Rivas-Mart. 1963 nom. inval. (ICPN arts. 2b, 3b, 8)}

The name was proposed by RIVAS GODAY \& Rivas-Martínez (1963: 132) as 'subgrupo Oligo-Bromion Rivas Goday \& Rivas-Martínez 1963 nova prov.' As stated in the Preamble of his book «Estudio y clasificación de los pastizales españoles», the term 'subgrupo' (subgroup) was used by Rivas Goday as an equivalent to alliance (in a similar way the orders were named 'grupos'), and across the text both denominations have been frequently used in a coherent way. Nevertheless the name is invalid because it was proposed as provisional and without reference to any valid association name. The name-giving taxon is Bromus erectus (currently: Bromopsis erecta) the only species of this genus quoted among the character and differential species. Moreover, the shape of the alliance name was intended to differentiate it from the Mesobromion and the Xerobromion (Brometalia erecti).

\section{Oligo-Bromion Rivas Goday \& Rivas-Mart. in Rivas Goday 1964 nom. inval. (ICPN arts. 2b, 8)}

In this new proposal of Rivas GoDAY (1964) the provisional statement was removed and the diagnosis contains an association name ('SilenoLinetum') based on four relevés and a species list from the mountains of the southwestern Spain, as well as one unassigned relevé and two more relevés named 'Community Vicia onobrychioides et Linaria aeruginea prov.' from the Sierra of Guadarrama (Central Spain). It is obvious in the Rivas GODAY's (1964) book where an association was proposed and when not, and in the case of the name 'Sileno-Linetum' the denomination of 'community' was indicated unambiguously it is qualified as 'community' at least four times across the text, and the word 'association' has never used for it. The last sentence before the description of the alliance Oligo-Bromion reads: "The following fragmentary communities may be considered as a Brometalia [erecti] silicinea [silicicolous], and 
hence of [belonging to] Festuco-Sedetea..." (translated from Spanish). Therefore, in our opinion, the name 'Sileno-Linetum' is to be considered as a syntaxon without a rank and the name Oligo-Bromion should be considered invalid according to the ICPN arts. $2 \mathrm{~b}$ and 8 . Even if the 'Sileno-Linetum' was considered a valid association name, it would be the only valid element of the diagnosis and hence ICPN art. 3f should apply for the alliance name, because the table of 'Sileno-Linetum' does not contain any species of the genus Bromus. Although ICPN does not state unambiguously that only valid subordinated syntaxa must be considered when applying the ICPN art. $3 \mathrm{f}$ (see FERNÁNDEZ-GONZÁLEZ \& IZCO, 1995), it appears implicitly so, in accordance to general logic of the ICPN.

\section{Oligo-Bromion Rivas Goday et Ladero 1970 nom. inval. (ICPN arts. 2b, 8)}

The 'alliance Oligo-Bromion Rivas Goday \& Rivas-Martínez 1963' (with bibliographical reference) was described again by RIVAS GODAY \& LADERO (1970: 175-177). The new diagnosis contains only a list of species under the name 'communities of Oligo-Bromion'; no reference was made to the 'Sileno-Linetum' described by Rivas GODAY (1964). Therefore this name constitutes a nomen nudum.

\section{Oligobromenion G. López 1978 nom. inval. (ICPN art. 3f)}

LóPEZ (1978: 652, 657-659) proposed the rank of suballiance for the Oligo-Bromion Rivas Goday et Rivas-Mart. 1963. Despite a valid association name is given (PotentilloLeucanthemopsietum assoi G. López 1978), the suballiance name remains invalid because no species of the genus Bromus (as taxonomically delimited then) was present in the corresponding relevés. This association is currently ascribed to the alliance Hieracio castellaniPlantaginion radicatae (Jasiono-Koelerietalia)
(RIVAS-MARTÍNEZ \& al., 2001; see a previou note by J.-P. Theurillat on the nomenclature of this alliance included in this paper).

The Oligobromenion was classified by López within the alliance Bromion [erecti], and it was considered as "more xeric than Mesobromion". Nevertheless in the syntaxonomic scheme on page 601 the suballiance was wrongly classified in the 'Bromion racemosi Tx. 1951'. The pastures of the Oligobromenion are supported by moderately acidic substrates and identified as having a "transitional position between the Brometalia erecti and the Sedo-Scleranthetea". Obviously, the Oligobromenion G. López 1978 should be considered as a corresponding name in the synonymy of the Hieracio-Plantaginion.

\section{Establishing the synonymy for the Oligo- Bromion}

In its first proposal (RIVAS GODAY \& RIVASMARTínEZ, 1963: 134-135), the list of character and differential species is long but also vague, including species of dry perennial pastures today ascribed to several alliances of the Jasiono-Koelerietalia, Agrostietalia castellanae and Poetalia bulbosae, as well as annuals of the Helianthemetalia guttati, and a few basiphilous species that would establish a weak link with the Brometalia erecti (for the currently accepted nomenclature of the referred syntaxa we followed Rivas-Martínez \& al., 2001, 2002, 2011). The descriptions provided by the authors on the pastures included in the Oligo-Bromion and those of other related alliances suggest that closer links would correspond to the modern concepts of the Agrostion castellanae and the Hieracio castellani-Plantaginion radicatae.

Regarding the RIVAS GODAY's (1964) proposal, the four relevés ascribed to the SilenoLinetum include as many annual as perennial species. The composition of the former is similar to the Anthoxantho-Micropyretum patentis (Helianthemion guttati). The list of perennials is much more heterogeneous, but several species are related to the Hieracio-Plantaginion radicatae (Arenaria querioides, Leucanthemopsis 
pallida, Centaurea amblensis subsp. tentudaica and C. toletana; the reference to 'Centaurea tentudaica' in relevé 1 probably corresponds to $C$. toletana). The few supposedly basiphilous species present in the relevés (Linum marianorum, L. narbonense, Ranunculus gramineus and Valeriana tuberosa) have in fact scattered localities on siliceous substrates across the Western Iberian Peninsula. Hence a reasonable interpretation is that Rivas GODAY (1.c.) intended to sample communities of short perennial plants (embedded in annual pastures) growing on these siliceous mountains located to the south of the Iberian Central System. This concept would reinforce the relationships between the OligoBromion and the Hieracio-Plantaginion radicatae, however until today no association belonging to the latter alliance has been recognized as occurring in the southwestern Iberian mountains. The relevé 1069 (RIVAS GoDAY, 1964: 419) is very different due to the abundance of perennial mesophilous graminoids pointing to the relationship with the Agrostion castellanae grasslands. Finally, in the relevés of the community Vicia onobrychioides-Linaria aeruginea (p. 420), two thirds of species are annuals that would fit within the Hispidello hispanicae-Tuberarietum guttatae (Molineriellion laevis). Only five species (Linaria aeruginea, Plantago radicata, Corynephorus canescens, Centaurea alba, 'Hippocrepis comosa' [most probably $H$. carpetana according to CASTROviejo, 1999]) would relate these relevés to the Hieracio-Plantaginion.

The species list given by RIVAS GODAY \& LADERO (1970) comes from mid-mountain areas of the Sierra de Guadarrama (Central Spain) and is dominated by species related to the Agrostion castellanae grasslands, along with several annuals of the Helianthemetalia guttati, two species of the Hieracio-Plantaginion ('Festuca laevis' [most probably $F$. rivasmartinezii according to DEvesA \& al., 2013] and Dianthus laricifolius) and two species (Bromopsis erecta, Vicia onobrychioides) rare on the siliceous substrates prevalent in the Sierra de Guadarrama.

In conclusion, although a proper synonymy for the Oligo-Bromion cannot be established without ambiguity, yet most of the evidences points upon a relationship with dry, acidophilous, Central and Western Iberian pastures of the Hieracio castellani-Plantaginion radicatae. This statement fits perfectly in the case of the Oligobromenion G. López 1978, but it is weak in the 1970 proposal, and to an extent also for the 1963 and 1964 proposals, on account of other possible links with the Agrostion castellanae or the Helianthemetalia guttati.

NOMENCLATURE CORRECTION IN THE BROMO PANNONICI-FESTUCION

(by Ladislav Mucina)

Bromo pannonici-Festucion csikhegyensis Zólyomi 1966 corr. Mucina hoc loco

(Stipo pulcherrimae-Festucetalia pallentis, Festuco-Brometea)

CORReCTED NAME: Bromo pannonici-Festucion pallentis Zólyomi 1936 (Zólyomi, 1936: 146147).

SynONYMS: Seslerio-Festucion glaucae Klika 1931 nom. amb. rejic. propos. (ICPN art. 36); Seslerio-Festucion duriusculae Klika 1931 nom. mut. propos. et nom. amb. rejic. propos. (ICPN art. 36, mut. superfl.); Seslerio-Festucion pallentis Klika 1931 corr. Zólyomi 1966 nom. amb. rejic. propos. (ICPN art. 36, corr. superfl.); Festucion pallentis (Klika 1931) Korneck 1974 nom. dubium (ICPN art. 37).

DiAGNOSIS: Xerophilous rocky grasslands on calcareous substrates of the northern fringes of the Pannonian Basin (Southern Moravia, Southern Slovakia, Eastern Austria, Northern Hungary) and the Ukrainian Podolya (Eastern Ukraine).

KORNECK (1974) described the 'Festucion pallentis' and included into his alliance also then validly published concept of the SeslerioFestucion glaucae Klika 1931. However, even when the latter concept would be rejected as nomen ambiguum, the Festucion pallentis sensu KORNECK (1974) should not be considered as an acceptable syntaxonomic concept. This alliance 
lacks ecological and phytogeographic logic as it comprises virtually all dominated rocky grassland communities dominated by Festuca pallens group, including those on calcareous, siliceous, and ultramafic substrates that differ widely in floristic composition as well as in assembly genesis. The KORNECK's (1.c.) concept brought further confusion into the nomenclature intricate matters surrounding the communities dominated by taxa of Festuca ser. Psammophilae in Western and Central Europe and therefore should be considered nomen dubium.

The original suggestion by KLIKA (1931) to classify the Festuca-dominated xerophilous grasslands, together with dense-canopy subxerophilous relict Sesleria-dominated grasslands, into the 'Seslerio-Festucion' has been followed for many years. ZÓLYOMI (1966) introduced the 'Bromo-Festucion pallentis Zólyomi 66', yet still also comprising one Sesleria-dominated association - the 'Diantho lumnitzeri-Seslerietum variae Zlatnik (28), Klika 37 em. Zólyomi (36) 66’. Chytrý \& Mucina in Mucina \& KolBeK (1993: 460-461; see also TheuRILlat, 1997) suggested rejecting the name 'Seslerio-Festucion glaucae' and consequently all its 'corrected' and 'mutated' variants (e.g. Seslerio-Festucion pallentis sensu auct. and Seslerio-Festucion duriusculae sensu auct.) as nomina ambigua.

The taxonomic identity of the eponymous Festuca species in this context has always been very contentious (see MucINA \& KolBEK, 1993: 450). So far the most acceptable solution was presented by the study of ŠMARDA \& al. (2007) who suggested that the tetraploid 'Festuca pallens' along the northern fringes of the Pannonian region (and in its xero-thermophilous grassland vegetation) is actually Festuca csikhegyensis Simonk., a taxonomically, different concept from the diploid F. pallens Host. This fact underpins the necessity of the name correction as suggested above.

The Bromo pannonici-Festucion pallentis was typified by the 'Seseli leucospermiFestucetum pallentis Zólyomi 1936 corr. 1966' (see Mucina \& KolbeK, 1993). Here we perform a nomenclatural name correction (according to ICPN art. 43) of the original name and introduce:
Seseli leucospermi-Festucetum csikhegyensis Zólyomi 1936 corr. Mucina hoc loco

(Stipo pulcherrimae-Festucetalia pallentis, Festuco-Brometea)

Corrected nAme: 'Festuca glauca-Seseli leucospermum Ass.' (Zólyomi, 1936: 146-147)

\section{VALIDATION OF THE ORDER FOR THE SUBMEDITERRANEAN OLIGO-MESOTROPHIC GRASSLANDS OF THE SOUTHERN BALKANS \\ (by Ladislav Mucina \& Andraž Čarni)}

Armerietalia rumelicae V. Ranđelović et N. Ranđelović in Ranđelović et Zlatković ex Mucina et Čarni ord. nov. hoc loco

(Stipo giganteae-Agrostietea castellanae)

VALIDATED NAME: Armerietalia rumelicae V. Ranđelović et N. Ranđelović in Ranđelović et Zlatković 2010 (ICPN art. 5).

SYNONYMS: Armerietalia rumelicae V. Ranđelović et N. Ranđelović 2001 (phantom); Armerietalia rumelicae V. Ranđelović et al. 2008 nom. inval. (ICPN arts. 2b, 5).

NAME-GIVING SPECIES: Armeria rumelica.

Holotypus (hoc loco): Potentillo-Armerion Micevski 1978 (MicEVSKI, 1978: 21)

Diagnostic taXa: Agrostis castellana, Armeria rumelica, Centaurea stoebe subsp. serbica, Festuca panciciana, F. stojanovii, Pastinaca hirsuta, Potentilla inclinata, Plantago holosteum, Rhinanthus rumelicus, Trifolium velenovskyi, Dianthus cruentus, Viola tricolor subsp. macedonica.

DisTRIBUTION: southern and central regions of the Balkan Peninsula.

MicEVSKI (1978) described two associations (Genisto-Agrostietum byzanthinae and Koelerio-Festucetum stojanovii) from siliceousbedrocks, occurring at elevations 1000-1400 m, in the eastern regions of Macedonia. MICEVSKI (1.c.) further suggested that his two new associations should not be classified in the submediterranean Trifolion cherleri Micevski 1972 vegetation found on siliceous bedrock at lower 
elevations (up to $1000 \mathrm{~m}$ above sea level) and therefore described a new alliance - the Armerio-Potentillion that he classified in the Astragalo-Potentilletalia (MicevsKI, 1971). In the classification scheme, as adopted by the EuroVegChecklist (MucinA \& al., submitted), the Astragalo-Potentilletalia (FestucoBrometea) comprises only open calcicolous grasslands of the Saturejo-Thymion. The Trifolion cherleri represents submediterranean therophyte communities in the Southern Balkans, classified in the Helianthemetalia guttati Br.-B1. in Br.-B1. \& al. 1940 (Helianthemetea guttati Rivas Goday et RivasMart. 1963). The Potentillo-Armerion cannot be classified into either the AstragaloPotentilletalia or in the Helianthemetalia guttati. This vegetation is perennial grassland supported by nutrient-poor soils on siliceous bedrocks at elevations characterized by the submediterranean climate of Macedonia, Southern Serbia and Bulgaria.

The following associations have so far been classified in the Potentillo-Armerion:

Genisto-Agrostietum byzanthinae Micevski 1978

Koelerio-Festucetum stojanovii Micevski 1978

Diantho-Armerietum rumeliacae N.

Ranđelović 1978 (ICPN art. 1)

Danthonio-Trifolietum velenovskyi

Ranđelovič 1978 (ICPN art. 1)
Similar vegetation was described or reported from southeastern Serbia by N. RANĐELOvić (1978), Milosavljević \& al. (2008), RANĐELOVIĆ \& al. (2008) and V. RANĐELOVIĆ \& ZlatKović (2010). In the latter two papers, this vegetation was classified in the PotentilloArmerion. V. RanĐelović \& Zlatković (2010) proposed classification of the PotentilloArmerion into a new order - the Armerietalia rumelicae, however since they failed to designate the holotypus in expressis verbis (as required by the ICPN after 1.1.2002), the order name remained invalid. We agree with the syntaxonomic concept of the new order suggested by RANĐELOVIĆ \& ZlatKOVIĆ (2010) and therefore formally validate the Armerietalia rumelicae herein.

\section{ACKNOWLEDGEMENTS}

We thank all the institutions and the persons who helped us in providing information and bibliographical references, in particular the library of the Conservatoire botanique in Geneva, the Conservatoire botanique national de Bailleul (France), Helga Bültmann, Jürgen Dengler, N. Hartmut Dierschke and Nicolas Fumeaux. Paul Macintyre kindly checked our English.

\section{REFERENCES}

Abbate, G., Cesca, G., Codogno, M., Corbetta, F. \& Puntillo, D. - 1984 - Sindinamica di fitocenosi prative della Sila Grande (Calabria) — Biogeographia 10: 161178.

Allegrezza, M. - 2003 - Vegetazione e paesaggio vegetale della dorsale del Monte San Vicino (Appennino centrale) - Fitosociologia 40(1), Suppl. 1: 3-118.

Apostolova, I., Dengler, J., Di Pietro, R., Gavilán, R.G. \& Tsiripidis, I. - 2014 - Dry grasslands of Southern Europe: syntaxonomy, management and conservation - Hacquetia 13 (1): 1-14.

Barbero, M. \& Loisel, R. —1972- Contribution à l'étude des pelouses à Brome méditerranéennes et méditer- ranéo-montagnardes — An. Inst. Bot. Cavanilles 28: 91165.

Barcella, M., Assini, S. \& Ardenghi, N.M.G. -2014- A phytosociological survey of semi-dry mountain grasslands in the northern Apennines - In: Atti del $48^{\circ}$ Congresso. Scienza della vegetazione e monitoraggio della Biodiversità. Pp. 23. Sapienza Univ. Roma, Roma.

Bartolucci, F. \& Domina, G. - 2014- Typification and taxonomic characterization of Thymus longicaulis $\mathrm{C}$. Presl (Lamiaceae) - Ann. Bot. Fenn. 51: 54-62.

Bernardo, L., Codogno, M. \& Puntillo, D. -1991 - The floristic composition of the Sila. Greca pastures (Calabria, S-Italy) — Stud. Geobot. 10: 59-70. 
Biondi, E., Allegrezza, M., Casavecchia, S., Galdenzi, D., Gasparri, R., Pesaresi, S., Poldini, L., Sburlino, G., Vagge, I. \& Venanzoni, R. —-2015- New syntaxonomic contribution to the Vegetation Prodrome of Italy Plant Biosyst. 149: 603-615.

Biondi, E., Allegrezza, M. \& Zuccarello, V. —2005Syntaxonomic revision of the Apennine grasslands belonging to Brometalia erecti, and an analysis of their relationships with the xerophilous vegetation of Rosmarinetea officinalis (Italy) - Phytocoenologia 35: 129-164.

Biondi, E., Ballelli, S., Allegrezza, M., Guitian, J. \& Taffetani, F. - 1986- Centaureo bracteatae-Brometum erecti ass. nova dei settori marnoso-arenacei dell'Appennino centrale - Doc. Phytosociol. 10: 117-126.

Biondi, E., Ballelli, S., Allegrezza, M. \& Zuccarello, V. 1995- La vegetazione dell'ordine Brometalia erecti Br.-Bl. 1936 nell'Appennino (Italia) — Fitosociologia 30: 3-45.

Biondi, E., Filigheddu, R. \& Farris, E. -2001- Il paesaggio vegetale della Nurra (Sardegna nord-occidentale) - Fitosociologia 38(2), Suppl. 2: 3-105.

Biondi, E., Vagge, I., Baldoni, M. \& Taffetani, F. — 1999La vegetazione del Parco Fluviale Regionale dello Stirone (Emilia-Romagna) — Fitosociologia 36: 67-83.

Blasi, C., Burrascano, S., Del Vico, E., Iocchi, M., Di Pietro, R. \& Rosati, L. -2009- Cynosurion cristati grasslands in the central Apennines (Tyrrhenian sector): A phytosociological survey in the Lepini and Prenestini mountains - Plant Biosyst. 143: 69-77.

Blasi, C. \& Di Pietro, R. - 1998 - Two new phytosociological types of Quercus pubescens s.l. woodland communities in southern Latium - Plant Biosyst. 132: 207-223.

Blasi, C., Di Pietro, R. \& Fortini, P. - 2000 - A phytosociological analysis of abandoned terraced olive grove shrublands in the Tyrrhenian district of Central Italy Plant Biosyst. 134: 305-331.

Blasi, C., Di Pietro, R., Filesi, L. \& Fortini, P. —2001Syntaxonomy, chorology and syndynamics of Carpinus orientalis communities in Central Italy Phytocoenologia 31: 33-62.

Blasi, C., Facioni, L., Burrascano, S., Del Vico, E., Tilia, A. \& Rosati, L. - 2012 - Submediterranean dry grasslands along the Tyrrhenian sector of central Italy: synecology, syndynamics and syntaxonomy — Plant Biosyst. 146: 266-290.

Bonanomi, G. \& Allegrezza, M. -2004- Effetto della colonizzazione di Brachypodium rupestre (Host) Roemer et Schultes sulla diversità vegetale in un settore dell'Appennino umbro-marchigiano — Fitosociologia 41 (2): 51-69.

Bonanomi, G., Caporaso, S. \& Allegrezza, M. - 2006Short-term effect of nitrogen enrichment, litter removal and cutting on a Mediterranean grassland - Acta Oecol. 30: 419-425.
Bonin, G. - 1978 - Contribution à la connaissance de la végétation des montagnes de l'Apennin centro-meridional — PhD Thesis, Univ. Marseille, Marseille.

Boşcaiu, N. -1972 - Xeric grasslands (Festuco-Brometea Br.-B1. 43) in the Caransebeş-Mehadia depression Act. Hort. Bot. Bucureşti 1970-1971: 449-468. (in Romanian).

Boşcaiu, N. \& Resmeriţă, I. —1969- The xerophilous grassland vegetation on the alluvia in Valea Eşelniţa Valea Mraconiei of the Danube Gorge - Stud. Cerc. Biol., Ser. Bot. 21: 209-216. (in Romanian).

Braun-Blanquet, J. \& Moor, M. —1938 - Prodromus der Pflanzengesellschaften. Fasc. 5. Verband des Bromion erecti - S.I.G.M.A., Montpellier.

Braun-Blanquet, J., Roussine, N. \& Nègre, R. —1952Les groupements végétaux de la France méditerranéenne - Cent. Nat. Rech. Sci., Paris.

Brullo, S., Cormaci, A., Giusso Del Galdo, G., Guarino, R., Minissale, P., Siracusa, G. \& Spampinato, G. - 2005A syntaxonomical survey of the Sicilian dwarf shrub vegetation belonging to the class Rumici-Astragaletea siculi - Ann. Bot. N.S. 5: 103-149.

Brullo, S., Gangale, C. \& Uzunov, D. -2004- The orophilous cushion-like vegetation of the Sila Massif (S Italy) — Bot. Jahrb. Syst. 125: 453-488.

Brullo, S., Gangale, C. \& Uzunov, D. -2007Taxonomic remarks on the endemic flora of the Sila Mountain (S Italy) - Bocconea 21: 213-222.

Brullo, S. \& Grillo, M. - 1978 - Ricerche fitosociologiche sui pascoli dei Monti Nebrodi (Sicilia settentrionale) - Notiz. Soc. Ital. Fitosoc. 13: 23-61.

Brullo, S., Scelsi, F. \& Spampinato, G. -2001 - La vegetazione dell'Aspromonte — Laruffa Ed., Reggio Calabria.

Buia, A., Pãun, M., Safta, I. \& Pop, M. -1959- A geobotanical contribution on the mesophilous grasslands surrounding Oltenia - Luc. Sti. Inst. Agron. T. Vladimir. Craiova 1959: 1-90. (in Romanian).

Cano-Ortiz, A., Biondi, E., Pinto Gomes, C.J., Del Río González, S. \& Cano, E. -2014- Soil and Phytosociological characterisation of grasslands in the western Mediterranean - Am. J. Plant Sci. 5: 3213 3240 .

Capelo, J.H. - 1996 - Nota a sintaxonomia das orlas herbáceas florestais do SW da Península Ibérica. In: Notas do Herbário da Estação Florestal Nacional (LISFA): Fasc. III — Silva Lusit. 4: 123-125.

Castroviejo, S. (ed.) - 1999- Flora iberica. Plantas vasculares de la Península Ibérica e Islas Baleares. Vol. 7 R. Jard. Bot. CSIC, Madrid.

Costa, J.C., Capelo, J., Jardim, R., Sequeira, M., Espírito Santo, M.D., Lousã, M., Fontinha, S., Aguiar, C. \& Rivas-Martínez, S. -2004-Catálogo sintaxonómico e florístico das comunidades vegetais da Madeira e Porto Santo - Quercetea 6: 61-185. 
Costa, J.C., Ladero, M., Díaz, T.E., Lousã, M., Espírito Santo, M.D., Vasconcelos, T., Monteiro, A. \& Amor, A. —1993 - Guia Geobotânico da Excursão das XIII Jornadas de Fitossociologia - I.S.A., Lisboa.

Chytrý, M., Daniëls, F.J.A., Di Pietro, R., Koroleva, N. \& Mucina, L. - 2015- Nomenclature adjustments and new syntaxa of the arctic, alpine and oro-mediterranean vegetation - Hacquetia 14 (1): 103-114.

Chytrý, M., Hoffmann, A. \& Novák, J. —2007— Dry grasslands (Festuco-Brometea) — In: Chytrý, M. (Ed.). Vegetation of the Czech Republic. Grassland and heathland vegetation. Pp. 371-470. Academia, Praha. (in Czech).

Čarni, A. \& Mucina, L. - 2015- Validations and typifications of some south European syntaxa - Hacquetia 14 (2): 289-299.

Daniëls, F.J.A., Elvebakk, A., Matveyeva, N.V. \& Mucina, L. - 2015 - The Drabo corymbosae-Papaveretea dahliani a new vegetation class of the High Arctic polar deserts - Hacquetia doi: 10.1515/hacq-2015-0013.

De Foucault, B. —1994 [1993] — Essai synsystématique sur les pelouses sèches acidophiles (Nardetea strictae, Caricetea curvulae) - Coll. Phytosociol. 22: 431455.

De Foucault, B. - 2012 - Contribution au prodrome des végétations de France: les Nardetea strictae Rivas Goday in Rivas Goday \& Rivas-Mart. 1963 - J. Bot. Soc. Bot. France 59: 241-344.

Dengler, J. —2004 - Klasse: Festuco-Brometea Br.-B1. \& Tx. ex Klika \& Hadač 1944 - Basiphile Magerrasen und Steppen im Bereich der submeridionalen und temperaten Zone - In: Berg, C., Dengler, J., Abdank, A. \& Isermann, M. (Eds.). Die Pflanzengesellschaften Mecklenburg-Vorpommerns und ihre Gefahrdung. Textband. Pp. 327-335. Weissdorn, Jena.

Dengler, J., Becker, T., Ruprecht, E., Szabó, A., Becker, U., Beldean, M., Bita-Nicolae, C., Dolnik, C., Goia, I., Peyrat, J., Sutcliffe, L.M.E., Dan Turtureanu, P. \& Uğurlu, E. - 2012 - Festuco-Brometea communities of the Transylvanian Plateau (Romania), a preliminary overview on syntaxonomy, ecology, and biodiversity Tuexenia 32: 319-359.

Dengler, J., Berg, C., Eisenberg, M., Isermann, M., Jansen, F., Koska, I., Lobel, F., Manthey, M., Päzolt, J., Spangenberg, A., Timmermann, T. \& Wollert, H. 2003 - New descriptions and typifications of syntaxa within the project 'Plant communities of MecklenburgVorpommern and their vulnerability'. Part I — Feddes Reper. 114: 587-631.

Dengler, J., Rūsi ņ a, S., Boch, S., Bruun, H.H., Diekmann, M., Dierßen, K., Dolnik, C., Dupré, C., Golub, V.B., Grytnes, J.A., Helm, A., Ingerpuu, N., Löbel, S., Pärtel, M., Rašomavičius, V., Tyler, G., Znamenskiy, S.R. \& Zobel, M. — 2006 - Working group on dry grasslands in the Nordic and Baltic region. Outline of the project and first results for the class Festuco-Brometea - Ann. Bot. S.N. 6: 1-28.
Devesa, J.A., Catalán, P., Müller, J., Cebolla, C. \& Ortúñez, E. - 2013 - Checklist de Festuca L. (Poaceae) en la Península Ibérica — Lagascalia 33: 183-274.

Di Pietro, R. - 2011 - New dry grassland associations from Ausoni-Aurunci mountains (central Italy). Syntaxonomical updating and discussion on the higher rank syntaxa - Hacquetia 10 (2): 183-231.

Di Pietro, R., Azzella, M.M. \& Facioni, L. —2010 - The forest vegetation of Tolfa-Ceriti mountains (northern Latium - Central Italy) - Hacquetia 9 (1): 5-64.

Di Pietro, R. \& Blasi, C. -2002- A phytosociological analysis of abandoned olive groves grasslands of Ausoni mountains (Tyrrhenian district of Central Italy) Lazaroa 23: 79-93.

Di Pietro, R., Conte, A.L. \& Iamonico, D. —2014- La vegetazione di San Martino D’Agri (Monografia e carta della Vegetazione) - Com. S. Martino D’Agri, Grafica Mente, Sant'Arcangelo.

Di Pietro, R. \& Germani, D. —2012 - La vegetazione In: Giardini, M. (Ed.). S. Angelo Romano (Monti Cornicolani, Roma). Un territorio ricco di Storia e di Natura - Comune di Sant'Angelo Romano. Pp. 112133. Regione Lazio, Assess. Amb. Svil. Sost., Tivoli.

Díaz González, T.E. \& Fernández Prieto, J.A. —1994—La vegetación de Asturias - Itinera Geobot. 8: 243-528.

Didukh, Y.P. \& Mucina, L. - 2014- Validation of the name of some syntaxa of Crimean vegetation Lazaroa 35: 151-190.

Doniţă, N., Ivan, D., Coldea, G., Sanda, V., Popescu, A., Chifu, T., Paucă-Comănescu, M., Mititelu, D. \& Boşcaiu, N. - 1992 - The vegetation of Romania Tech. Agric., Bucureşti (in Romanian).

Euro+Med Plant Base -2006 onwardshttp://www.emplatbase.org

European Commission - 2013 - Interpretation Manual of European Union Habitats - Europ. Comm., Bruxelles.

Fanelli, G. - 1998 - Dasypyrum villosum vegetation in the territory of Rome - Rend. Linc. (Sci. Fis. Nat.) 9: 149-170.

Fanelli, G. — 2002 - Analisi fitosociologica dell'area metropolitana di Roma - Braun-Blanquetia 27: 1-276.

Fanelli, G. - 2011 - The ecology of Dasypyrum villosum in Italy: highlights from phytosociology - In: De Pace, C. (Ed.). Transferring genes from the wild species D. villosum to wheat for increasing adaptation to sustainable agricultural systems. Scritti e documenti, 44. Pp 105-119. Accad. Naz. Sci. XV, Roma.

Fanelli, G., De Sanctis, M., Gjeta, E., Mullaj, A. \& Attorre, F. - 2015 - The vegetation of the Buna river protected landscape (Albania) - Hacquetia 14 (2): 129-174.

Fanelli, G. \& Lucchese, F. - 1998 - The status of Brometalia rubenti-tectori communities from the Mediterranean area in different syntaxonomical schemes - Rend. Linc. (Sci. Fis. Nat.) 9: 241-255.

Fernández-González, F. \& Izco, J. —1995- On article 3f of the Code of Phytosociological Nomenclature - Folia Geobot. Phytotax. 30: 277-281. 
Ferro, G. - 1980 - La vegetazione di Butera (Sicilia meridionale) - Atti Istit. Bot. Lab. Crit. Univ. Pavia 13: 51-116.

Filigheddu, R., Farris, E., Bagella, S. \& Biondi, E. 1999 - La vegetazione della serie edafo-igrofila dell'olmo (Ulmus minor Miller) nella Sardegna nord-occidentale — Doc. Phytosociol. N.S. 19: 509-519.

Foggi, B., Lastrucci, L., Gennai, M. \& Viciani, D. 2014 - The Festuco-Brometea grasslands on sandstone and marl-clay-sandstone substrata in Tuscany (northerncentral Italy) - Hacquetia 13 (1): 19-54.

Gentile, S. —1962 - I pascoli del territorio di Ragusa. (Sicilia Meridionale-Orientale) - Delpinoa 5: 1-14.

Giacomini, V. \& Gentile, S. —1961- Observations synthétiques sur la végétation anthropogène montagnarde de la Calabre (Italie meridionale) — Delpinoa 3: 55-67.

Giacomini, V. \& Gentile, S. -1966- Observations synthétiques sur la végétation anthropogène montagnarde de la Calabre (Italie meridionale) — In: Tüxen, R. (Ed). Anthropogene Vegetation. Pp. 135-145. Dr W. Junk Publ., The Hague.

Gigante, D. \& Venanzoni, R. — 2007- Some remarks about the annual sub-nitrophilous vegetation of TheroBrometalia in Umbria (central Italy) - Lazaroa 28: 15-34.

Grigore, S. \& Coste, I. - 1974 - Botanical aspects of the Nature Reserve Valea Mare-Moldova Nouâ - Ocrot. Nat. Med. Inconj. Bucureşti 18: 159-166. (in Romanian).

Guglielmo, A., Pavone, P. \& Tomaselli, V. -2006Studio della vegetazione infestante e del verde ornamentale nel Parco Archeologico di Akrai (Palazzolo Acreide, SR) finalizzato alla conservazione e alla valorizzazione dei manufatti architettonici Fitosociologia 43 (1): 39-53.

Horvatić, S. -1958- Geographisch-typologische Gliederung der Niederungs-Wiesen und Weiden Kroatiens. Pflanzengeographischen Gebiete Kroatiens — Angew. Pflanzensoziol. 15: 63-73.

Horvatić, S. - 1963 - Vegetation map of the island Pag with general overview of vegetation units of Croatian coast - Acta Biol. 4: 3-187. (in Croatian).

Horvatić, S. - 1973 - Syntaxonomic analysis of the vegetation of dry grassland and stony meadows in Eastern Adriatic coastal Karts district based on the latest phytocoenological research — Fragm. Herbol. Jugoslav. 32: 1-15.

Horvatić, S. - 1975- Neuer Beitrag zur Kenntnis der Syntaxonomie der Trocken-Rasen und Steintriften Gesellschaften des ostadriatischen Karstgebietes - In: Jordanov, D., Bondev, I., Kožuharov, S., Kuzmanov, B., Palamarev, E. \& Velčev, V. (Eds.). Problems of Balkan flora and vegetation. Pp. 300-310. Bulgarian Academy of Sciences. Sofia.

Ilijanić, L., Gaži, V. \& Topić, J. —1972- Grasslands containing Chrysopogon gryllus in continental regions of West Croatia - Acta Bot. Croat. 31: 155-164.
Izco, J. - 1977- Revision sintética de los pastizales del suborden Bromenalia rubenti-tectori - Coll. Phytosociol. 6: 39-53.

Klika， J. - 1931- Studien über die xerothermen Vegetation Mitteleuropas. I. Die Pollauer Berge im südlichen Mähren - Beih. Bot. Centralbl. Abt. B 47: 343-398.

Korneck D. - 1974 - Xerothermvegetation in RheinlandPfalz und Nachbargebieten - Schriftenrh. Vegetkde. 7: $1-196$

Kovačević, J. —1959- Pregled tipova travnjaka s agrološkog gledišta područja bivših bosanskih kotara Sanski Most, Mrkonjić-Grad, Bosanski Petrovac i Lijevča Polja — Godiš. Biol. Inst. Univ. Sarajevu 1-2: 3-46. (in Croatian).

López, G. - 1978 - Contribución al conocimiento fitosociológico de la Serranía de Cuenca, II - An. Inst. Bot. Cavanilles 34: 597-702.

Lucchese, F. —1990 [1987] — Ruolo di alcune specie del genere Brachypodium nelle associazioni prative e forestali - Notiz. Soc. Ital. Fitosoc. 23: 173-188.

Lucchese, F., Persia, G. \& Pignatti, S. -1995- I prati a Bromus erectus Hudson dell'Appennino Laziale Fitosociologia 30: 145-180.

Lysenko, T. \& Mucina, L. - 2015- Nomenclatural notes on some alliances of the halophytic vegetation of Southern Ural and the Caspian Lowlands - Hacquetia 14 (2): 301-306.

Micevski, K. - 1971- Astragallo-Potentilletalia, new vegetation order of mountain pastures in Macedonia Prilozi MANU 2 (2): 15-23. (in Macedonian).

Micevski, K. -1978 - Typological investigation of the meadows and pastures in Maleš and Pijanec - In: Filipovski, G. (Ed.). Maleš and Pijanec 1. Vegetation. Pp. 9-41. MANU, Skopje. (in Macedonian).

Milosavljević, V.N., Ranđelović, V.N., Zlatković, B. \& Ranđelović, N.V. —2008 - Phytocenologic diversity of Krajište in southern Serbia — Nat. Montenegr. 7: 193-204.

Molinier, R. - 1934- Etudes phytosociologiques et écologiques en Provence occidentale - Ann. Mus. Hist. Nat. Marseille 27: 1-274.

Mucina, L. - 1991 - Vicariance and clinal variation in synanthropic vegetation - In: Nimis, P.L. \& Crovello, T.J. (Eds.). Quantitive approaches to phytogeography. Pp. 263-276. Kluwer, Dordrecht.

Mucina, L, Dengler, J., Bergmeier, E., Čarni, A., Dimopoulos, P., Jahn, R. \& Matevski, V. —2009- New and validated high-rank syntaxa from Europe Lazaroa 30: 267-276.

Mucina, L. \& Kolbek, J. - 1993 - Festuco-Brometea In: Mucina, L., Grabherr, G., Ellmauer, T. (Eds.). Die Pflanzengesellschaften Österreichs. Pp. 420-492. G. Fischer Jena.

Oberdorfer, E. - 1949— Pflanzensoziologische Exkursionsflora für Südwestdeutschland - E. Ulmer, Stuttgart. 
Păun, M., Popescu, G., Cartu, M. \& Cartu, D. -1970Aspects of vegetation between Berzasca and Pescari (jud. Caras-Severin) - An. Univ. Craiova, Ser. Biol. 1970: 61-70. (in Romanian).

Pedashenko, H., Apostolova, I., Boch, S., Ganeva, A., Janišová, M., Sopotlieva, D., Todorova, S., Ünal, A., Vassilev, K., Velev, N. \& Dengler, J. - 2013 - Dry grasslands of NW Bulgarian mountains: first insights into diversity, ecology and syntaxonomy — Tuexenia 33: 309-346.

Penas, A. \& Díaz-González, T.E. —1985- Datos sobre la alianza Corynephoro-Plantaginion radicatae Rivas Goday \& Rivas-Martínez 1963 nom. invers. RivasMartínez 1975 en el sector Orensano-sanabriense Acta Bot. Malacit. 10: 155-166.

Pignatti, E. \& Pignatti, S. -2014- Plant life of the Dolomites - Springer, Berlin.

Pignatti, S. — 1952 - Introduzione allo studio fitosociologico della Pianura Veneta Orientale con particolare riferimento alla vegetazione litorale - Arch. Bot. 28: 265-329.

Pirini, C.B., Tsiripidis, I. \& Bergmeier, E. -2014Steppe-like grassland vegetation in the hills around the lakes of Vegoritida and Petron, North-Central Greece Hacquetia 13 (1): 121-169.

Pirone, G., Frattaroli, A.R. \& Corbetta, F. - 1997Vegetazione, cartografia vegetazionale e lineamenti floristici della Riserva naturale 'Sorgenti del Pescara' (Abruzzo, Italia) - Univ. Stud. Aquila, Dip. Sci. Amb., L'Aquila.

Poldini, L. - 1989 - La vegetazione del Carso isontino e triestino - Ed. Lint, Trieste.

Poldini, L. - 1995- La classe Festuco-Brometea nell'Italia nordorientale — Fitosociologia 30: 47-50.

Poldini, L. \& Kaligarič, M. —1997— New contribution on the typology of the vegetation of dry grasslands (Scorzoneretalia villosae H-ić 1975) in the north Adriatic Karst — Gortania 19: 119-148.

Preising, E. - 1943 - Die Waldgesellschaften des Wartheund Weichsellandes - Zentral. Veg. Reich., Stolzenau/Weser.

Preising, E. — 1949 - Nardo-Callunetea. Zur Systematik der Zwergstrauch-Heiden und Magertrifften Europas mit Ausnahme des Mediterran-Gebietes, der Arktis und der Hochgebirge - Mitt. Florist-Soziol. Arbeitsgem. N.F. 1: 82-94.

Preising, E. - 1950 - Nordwestdeutsche BorstgrasGesellschaften - Mitt. Florist-Soziol. Arbeitsgem. N.F. 2: 33-41.

Preising, E. - 1955- Nardo-Callunetea. Zur Systematik der Zwergstrauch-Heiden und Magertrifften Europas mit Ausnahme des Mediterran-Gebietes, der Arktis und der Hochgebirge - Mitt. Florist-Soziol. Arbeitsgem. N.F. 1: 12-25.

Quézel, P. -1953- Contribution à l'étude phytosociologique et géobotanique de la Sierra Nevada - Mém. Soc. Brot. 9: 5-77.

Ranđelović, N. -1978 - Phytocenological-ecological characteristics of hilly region grasslands of southeastern
Serbia - PhD thesis, Prirodoslovno-matematički fakultet, Zagreb.

Ranđelović, V.N. \& Zlatković, B.K. -2010- Flora and vegetation of Vlasina plateau - Prirodno-matematički fakultet, $\mathrm{N}$.

Ranđelović, V.N., Zlatković, B.K., Milosavljević, V.N. \& Ranđelović, N.V. - 2008 - The endemic flora of Bosilegrad surroundings (Krajişte region) in SE Serbia - Phytol. Balcan. 14: 367-375.

Raţiu, O. - 1968 - Phytocoenological research in the grassland vegetation of the Peninsula Ada-Kaleh Contr. Bot. 1968: 189-207. (in Romanian).

Redžić, S - 1999 - The syntaxonomic differentiation of the Festuco-Brometea Br.-B1. \& R. Tx. 1943 ex Klika \& Hadač 1944 in the Balkans - Ann. Bot. S.N. 57: 167180.

Redžić, S., Trakić, S. \& Barudanović, S. -2013- Patterns of vegetation diversity of grasslands and pastures Crvanj Mt. (Herzegovina, Western Balkan) - Sci. Res. Ess. 8: 1944-1965.

Rivas Goday, S. - 1956 - Aportaciones a la fitosociología hispánica. (Proyectos de comunidades hispánicas). Nota 1 - An. Inst. Bot. Cavanilles 13: 333-422.

Rivas Goday, S. - 1958 - Nuevos órdenes y alianzas de Helianthemetea annua Br. B1. - An. Inst. Bot. Cavanilles 15: 539-651.

Rivas Goday, S. —1964 - Vegetación y flórula de la cuenca extremeña del Guadiana (vegetación y flórula de la Provincia de Badajoz) - Dip. Prov. Badajoz, Madrid.

Rivas Goday, S. \& Borja Carbonell, J. —1961- Estudio de vegetación y flórula, del Macizo de Gúdar y Jabalambre — An. Inst. Bot. Cavanilles 19: 3-550.

Rivas Goday, S. \& Ladero, M. — 1970 - Pastizales cespitosos de Poa bulbosa L. Origen, sucesión y sistemática — An. R. Acad. Nac. Farm. 36: 139-181.

Rivas Goday, S. \& Mayor López, M. —1966- Aspectos de la vegetación y flora orófila del Reino de Granada An. R. Acad. Nac. Farm. 31: 34-400.

Rivas Goday, S. \& Rivas-Martínez, S. —1963 - Estudio y clasificación de los pastizales españoles - Min. Agric., Madrid.

Rivas-Martínez, S. - 1960 - Roca, clima y comunidades rupícolas. Sinopsis de las alianzas hispanas de Asplenietea rupestris - An. R. Acad. Nac. Farm. 26: 153-168.

Rivas-Martínez, S. —1964 [1963] — Estudio de la vegetación y flora de las Sierras de Guadarrama y Gredos - An. Inst. Bot. Cavanilles 21: 5-325.

Rivas-Martínez, S. - 1975 - Mapa de vegetación de la provincia de Avila - An. Inst. Bot. Cavanilles 32: 1493-1556.

Rivas-Martínez, S. \& Cantó, P. -1987- Datos sobre la vegetación de las Sierras de Guadarrama y Malagón Lazaroa 7: 235-257.

Rivas-Martínez, S., Díaz, T.E., Fernández-González, F., Izco, J., Loidi, J., Lousã, M. \& Penas, A. -2002- 
Vascular plant comunities of Spain and Portugal Itinera Geobot. 15: 5-922.

Rivas-Martínez, S., Díaz, T.E., Fernández Prieto, J.A., Loidi, J. \& Penas, A. —1984- Los Picos de Europa: la vegetación de la alta montaña cantábrica — Ed. Leonesas, León.

Rivas-Martínez, S. \& Fernández-González, F. —1991Validating the alliance Agrostio-Stipion giganteae Lazaroa 12: 383-386.

Rivas-Martínez, S. \& Izco, J. —1978 - Sobre la vegetación terofítica subnitrófila mediterranea (Brometalia rubenti-tectori) - An. Inst. Bot. A.J. Cavanilles 34: 355-381.

Rivas-Martínez, S., Díaz, T.E., Fernández-González, F., Izco, J., Loidi, J., Lousã, M. \& Penas, A. —2002Vascular plant communities of Spain and Portugal. Addenda to the Syntaxonomical Checklist of 2001 Itinera Geobot. 15: 5-922.

Rivas-Martínez, S., Fernández-González, F., Loidi, J., Lousã, M. \& Penas, A. —2001- Syntaxonomical checklist of vascular plant communities of Spain and Portugal to association level - Itinera Geobot. 14: 5341.

Rivas-Martínez, S., Wildpret, W., Del Arco, M., Rodríguez, O., Pérez de Paz, P.L., García Gallo, A., Acebes, J.R., Díaz, T.E. \& Fernández-González, F. —1993 - Las comunidades vegetales de la Isla de Tenerife (Islas Canarias) - Itinera Geobot. 7: 169-374.

Rivas-Martínez, S. y coautores - 2011 - Mapa de series, geoseries y geopermaseries de vegetación de España. [Memoria del mapa de vegetación potencial de España]. Parte II - Itinera Geobot. 18: 5-800.

Rodwell, J.S. (Ed.) - 1992- British plant communities. Volume 3. Grassland and montane communities Cambridge, Cambridge Univ. Press.

Rodwell, J.S., Schamineé, J.H.J., Mucina, L., Pignatti, S., Dring, J. \& Moss, D. - 2002 - The diversity of European vegetation - An overview of phytosociological alliances and their relationships to UNIS habitats Nat. Ref. Cent. Agric. Nat. Fish., Wageningen.

Roman, N. - 1974 - Flora and vegetation of the South Podişului Mehedinţi — Editura Academiei Române, Bucureşti. (in Romanian).

Royer, J.-M. — 1991 - Synthèse eurosibérienne, phytosociologique et phytogéographique de la classe des Festuco-Brometea - J. Cramer, Stuttgart.
Sanda, V., Öllerer, K. \& Burescu, P. -2008Phytocoenosis of Romania - Ars Docendi, Bucureşti. (in Romanian)

Schwickerath, M. - 1944- Das Hohe Venn und seine Randgebiete - G. Fischer Jena.

Seliškar, A. — 1998 - The habitat mapping in Slovenia Connection to the vegetation - Ann. Bot. S.N. 56: 101108.

Šmarda, P., Šmarda, J., Knoll, A., Bureš, P. \& Danihelka, J. -2007- Revision of Central European taxa of Festuca ser. Psammophilae Pawlus: morphometrical, karyological and AFLP analysis - Plant Syst. Evol. 266: 197 232.

Terzi, M. - 2015- Numerical analysis of the order Scorzoneretalia villosae - Phytocoenologia 45: 11-32.

Theurillat, J.-P. — 1997 - Index of proposals to correct, to inverse, to reject, and to conserve names of syntaxa in 1993 - Bot. Helv. 107: 263-269.

Theurillat, J.-P., Aeschimann, D., Küpfer, P. \& Spichiger, R. - 1995 - The higher vegetation units of the Alps Coll. Phytosociol. 23: 189-239.

Tüxen, R. (Ed.) - 1974 - Bibliographia Phytosociologica Syntaxonomica. Lieferung 20. Nardo-Callunetea - J. Cramer, Stuttgart.

Ubaldi, D. - 1988 - Nuove associazioni vegetali del Montefeltro e dell'alta Valle del Foglio - Proposte e Ricerche 20: 38-47.

Ubaldi, D. - 1997- Geobotanica e Fitosociologia Clueb, Bologna.

Ubaldi, D. -2003 - Flora, fitocenosi e ambiente. Elementi di Geobotanica e Fitosociologia - Clueb, Bologna.

Ubaldi, D. -2011 [2008]— Le vegetazioni erbacee e gli arbusteti italiani - Aracne, Roma.

Vigo i Bonada, J. -1968 - La vegetació del massís de Penyagolosa - Arx. Sec. Ci. Inst. Est. Catal. 37: 1-247.

Weber, H.E., Moravec, J. \& Theurillat, J.P. —2000International Code of Phytosociological Nomenclature. $3^{\text {rd }}$. edition - J. Veg. Sci. 11: 739-768.

Zólyomi, B. - 1936 - A survey of the rock cliff vegetation of the Pannonian province and the region bordering to the northwest - Ann. Hist.-Nat. Mus. Nat. Hung., Pars Bot. 30: 136-174. (in Hungarian).

Zólyomi, B. - 1966- A new classification of the rocky grasslands in and around the the Pannonian flora region — Bot. Közlem. 53: 49-54. (in Hungarian). 